IZADP No. 2152

China's Lesser Known Migrants

Deng Quheng

Bj orn Gustafsson

May 2006 


\title{
China's Lesser Known Migrants
}

\author{
Deng Quheng \\ Chinese Academy of Social Sciences \\ Bjorn Gustafsson \\ University of Göteborg \\ and IZA Bonn
Discussion Paper No. 2152
May 2006

\author{
IZA \\ P.O. Box 7240 \\ 53072 Bonn \\ Germany \\ Phone: +49-228-3894-0 \\ Fax: +49-228-3894-180 \\ Email: iza@iza.org
}

\begin{abstract}
Any opinions expressed here are those of the author(s) and not those of the institute. Research disseminated by IZA may include views on policy, but the institute itself takes no institutional policy positions.

The Institute for the Study of Labor (IZA) in Bonn is a local and virtual international research center and a place of communication between science, politics and business. IZA is an independent nonprofit company supported by Deutsche Post World Net. The center is associated with the University of Bonn and offers a stimulating research environment through its research networks, research support, and visitors and doctoral programs. IZA engages in (i) original and internationally competitive research in all fields of labor economics, (ii) development of policy concepts, and (iii) dissemination of research results and concepts to the interested public.
\end{abstract}

IZA Discussion Papers often represent preliminary work and are circulated to encourage discussion. Citation of such a paper should account for its provisional character. A revised version may be available directly from the author. 


\section{ABSTRACT}

\section{China's Lesser Known Migrants}

In China hukou (the household registration system) imposes barriers on permanent migration from rural to urban areas. Using large surveys for 2002, we find that permanent migrants number about 100 million persons and constitute approximately 20 percent of all urban residents. Receiving a long education, being a cadre or becoming an officer in the People's Liberation Army are important career paths towards urbanisation and permanent migrants are much better-off then their counterparts left behind in rural China. The probability of becoming a permanent migrant is positively related to parental education, belonging to the ethnic majority and the parent's membership in the Communist Party. At the destination, most permanent migrants are economically well-integrated. They have a higher probability to be working than their urban-born counterparts and those who receive a hukou before age 25 typically earn at least as much as their urban-born counterparts. The exceptions for this are those permanent migrants who receive a hukou after age 25 and people who received their hukou through informal routes.

JEL Classification: J61, O15, P36

Keywords: China, hukou, rural-to-urban migration

Corresponding author:

Bjorn Gustafsson

Department of Social Work

University of Göteborg

P.O. Box 720

SE 40530 Göteborg

Sweden

Email: Bjorn.Gustafsson@socwork.gu.se 


\section{Introduction}

Since its introduction during the planning period in the 1950s, a urban hukou (household registration) has been mandatory for people living in urban China. ${ }^{1}$ This system has put barriers on migration from rural to urban areas and has contributed to the large divide in living standards between the more affluent urban residents and their less fortunate rural counterparts. (Chan, 1994, Yang and Zhou, 1997, Zhao and Liu, 1997, Knight and Song, 1999, Zhao and Li, 1999, Zhao, 2000, Liu 2005 and UNDP, 2005)

After the introduction of economic reform, the Chinese economy has grown rapidly and more people than ever live in urban areas. Some enter as temporary migrants without possessing a hukou. Most such migrants are young manual labourers with lower-paid jobs. Typically, temporary migrants are disadvantaged when compared to urban residents regarding housing, protection for income loss and access to social services. They make up a lower stratum at the urban destination (Wang and Zuo, 1999, Zhao, 2000, Meng and Zhang, 2001, Cai et al., 2001; Cai et al, 2003, UNDP, 2005).

Other rural-born persons who have entered urban China have received a hukou by one of several routes. There are career routes by being more highly educated, being promoted as cadres or joining the People's Liberation Army. In addition, one can receive a hukou for family reasons, if land is transformed into urban use by the government, when buying a house at some cities, and even through purchase from the local government (Wong and Wai-Po, 1998, Lu, 2002, Chan, 2004).

This paper aims to shed new light on the flow of permanent migrants. It is far from the first study to investigate the permanent rural to urban migration in contemporary China. However, several key aspects of the permanent migration flow of rural-born persons to urban China appear to be unknown. These include basic information on the size of the population and what characterises the population and its cities. There is a lack of knowledge of the factors for predicting who will become a permanent migrant and who will remain in the rural setting. Further, it appears that only limited knowledge exists on the degree of assimilation or integration of the permanent migrants at the urban destination. 
Our research questions are numerous. How large is the population of permanent rural to urban migrants and what characterises it? What characterises the cities in which the migrants live? What kind of family background do the permanent migrants come from? Do permanent migrants fare better than their rural peers who were left behind? (We expect this to be the case based on the knowledge that the urban to rural income gap in China is rather large.) If yes, then how large is the income gap? Turning to the destination, we are interested in how well permanent migrants assimilate into the emerging labour market at the destination. Is it possible to show that those who received a hukou through career channels are in a better situation than those who received it though other channels?

We expect rural-born permanent migrants living in urban China to fare well at the destination, although they might be at a disadvantage when newly arrived, a phenomenon often found in the literature on international migration. Many permanent migrants are highly educated and a large fraction are members of the Communist Party, circumstances that should indicate their being well established in most spheres of life. Further, most permanent migrants are ethnically similar to people at the destination and speak the same language, although with some accent. There are even arguments for expecting permanent migrants to do better than urban born residents possessing the same observed characteristics. Permanent migrants have been able to seize the opportunity and move from an unfavourable environment; therefore they can be expected to be more capable of finding opportunities at the destination than others. However, there is also an argument for expecting rural-born permanent migrants to do more poorly than their urban-born counterparts. China is known for personal connections being important in many aspects of life. Permanent migrants have had less time to build up a functional network in urban areas and might therefore be at a disadvantage when seeking jobs and being promoted to better-paid jobs. The question is therefore open if permanent migrants at the destination do better or worse than their urban resident peers.

The rest of the paper is structured as follows: In the next section the history and evolution of the hukou system is described. Most often research on migrants focuses on circumstances at the origin or at the destination. However, in this paper we combine perspectives, which is made possible by our data; Section 3 presents the large surveys for 2002. We depict permanent migrants and locations in which they live in Section 4. In Section 5 we address research questions referring to origin, in Section 6 we investigate if permanent migrants assimilate into the labour market of the destination, and in Section 7 we examine if those who 
received a hukou through career channels are in a better situation than those who received it through other channels. Finally Section 8 summarises the study and its findings.

\section{The hukou system ${ }^{2}$}

Before 1949, when the Chinese Communist Party came into power, the movement of people throughout China was not restricted. Modelled on Soviet practice, the hukou system came into existence first in cities, then was extended to rural areas in 1955. All inhabitants were registered at the premises where they resided and then categorised. Hukou status cannot be changed easily, especially the conversion from rural to urban hukou. Within families, spouses were not necessarily categorised identically and children followed the classification of the mother. The phenomenon of the hukou, then, means that rural and urban residents in China should be viewed as two separate populations regarding more or less all spheres of life. A considerable amount of policymaking in China follows this division.

The introduction of the hukou system took place and was integrated with the creation of the planned economy. In cities (which were prioritised), work units were established. The workers typically had a long-term relation to their work unit; they were provided with housing, subsidised food, social benefit and old-age pensions. Individuals were allowed to move only when assigned new posts by the work unit or by the government. If one was not a member of a work unit, it was difficult to survive in a city because food, housing and social services were only of limited availability on the market. On the rural side, the commune system enabled local governments to tie peasants to the land. All adults had to participate in agricultural production to receive food rations. The communes had to deliver quotas to the government, thus helping to finance the industrialisation that took place in urban locations. In such a system, a person's fortune is very much linked to where he or she was born. The urban-born expect to be first-class citizens whereas the rural-born are relegated to being second-class citizens, unless they are able to migrate to urban areas and change registration.

Similar to most countries where aliens can become citizens, certain routes exist for rural-born persons in China to receive a hukou. Let us first discuss three routes that have been in force for some time. One is education. According to regulations, students are typically granted urban hukou status upon admission to a specialized secondary or tertiary school. Such educations are, in principle, open to all on the basis of merit. Rural-born persons who have 
become urban citizens via this route are thus typically longer educated, and the conversion typically took place before or at the very beginning of working life. These characteristics do not necessarily apply to persons who received a hukou by joining the Chinese Communist Party; in fact, not all rural party members are automatically entitled to a hukou. However, he (or less likely she) may be able to serve as rural cadre (that is village head, village party secretary, head of village enterprise, or village accountant). Some are promoted to higher leadership levels, and being part of the state bureaucratic system, are eligible to receive a hukou. A route still open for men (which could be combined with the previous situations) is to receive a hukou by joining the People's Liberation Army. After being discharged, a former PLA officer can obtain an urban job directly and change hukou status. ${ }^{3}$

In addition to the three career routes there are other routes for receiving a hukou. Family members can apply. It is important to note, however, that spouses do not have the right to receive a hukou immediately after marrying; many couples in China have lived separated from each other for years. Households having user rights to agricultural land can receive hukou as compensation if land is converted to urban use (See Wong and Wai-Po, 1998). In some cities, a more recent route for people with means is to procure a hukou through buying housing in an urban area, while some local governments sell urban hukou to meet financial needs.

Following the rapid influx of rural inhabitants during the turmoil and administrative collapse of the Great Leap Forward at the end of the 1950s, the hukou system effectively kept the inflow of rural inhabitants very low for many years. It has also restricted inter-urban migration as a hukou in one urban location is not easily transferred to another. However, the economic reforms that were introduced in rural areas at the end of the 1970s meant increased opportunities for many rural inhabitants to change their lives. Many saw the chance to urbanise and relocated as temporary workers without receiving a hukou. In urban areas, ties between workers and their work units have loosened since the 1980s, and consumer goods and housing are no longer administratively allocated. To be self-employed as a domestic worker or to be a wage earner in the construction sector without having a hukou has become a possible strategy for living in urban areas and the temporary rural to urban migration has accelerated. Compared to when it was originally institutionalised, the hukou system nowadays is operating in a rather different environment and is becoming less restrictive. ${ }^{4}$ 


\section{Data}

The data for this study comes from three coordinated household surveys conducted in 2002 for the research project "Income Distribution, Growth and Public Policy in China”, which involved a group of researchers at the Institute of Economics, Chinese Academy of Social Sciences, Beijing and scholars from other countries. The project was economically supported by the Ford Foundation in Beijing and SIDA (Swedish International Development Agency). The project was assisted by the General Team of Rural Surveys and General Team of Urban Surveys at the National Bureau of Statistics (NBS) that conducted the fieldwork in the beginning of 2003. The questionnaires were designed by the project team to meet the needs of research. $^{5}$

The survey of urban residents covers 2 municipalities and 10 provinces, from which a sample of 6835 households living in 77 cities was obtained. Both the urban and rural samples were drawn from larger samples regularly used by NBS to produce official statistics for China. The sample frame for the urban sample is based on registers of people possessing a hukou. This sample will be used to identify permanent migrants in the next section. This sample of urban residents will also form the basis for the analysis of income assimilation of permanent migrants reported in Sections 6 and 7. The urban sample will also be used to estimate the size of permanent migrants and analyze their destinations.

A second survey covers temporary rural to urban migrants living in the same municipalities and provinces as the survey of urban residents. It is experimental in the sense that, by definition, no sample frame exists from which to draw all types of temporary migrants. Shortterm rural migrants living in dormitories and/or at urban work places are rather difficult to identify, while rural migrants with housing conditions similar to the registered urban population can be simpler to identify and sample; our sample of temporary migrants has this character. This sample of 2000 households is used in Section 5 when comparing permanent and temporary migrants and when investigating the economic benefits from migrating.

The third sample covers rural households in 22 provincial level units comprising 122 counties or towns from which 9200 households were selected. We use this sample in Section 5 when analysing who becomes a permanent migrant and when investigating the economic benefits of migration. 


\section{Counting Permanent Migrants and Characterising their Destinations}

In the sample of urban residents we identify permanent migrants by the answers to the question: "When did you receive an urban hukou?” Out of 20082 individuals with local urban hukou in the urban households sampled, 4069 indicated that they were rural-born or received an urban hukou later in their lives; they make up 20.3 percent of the urban resident population. According to NBS, the population of registered urban persons in 2004 numbered 543 million. From this we derive probably the first estimate of the size of the permanent rural to urban migration population in China - 110 million persons. This means a magnitude similar to the temporary migration population in 2004, which is counted as 120 million (State Council, 2006, p 4). ${ }^{6}$ If we define the "true" urban population as the sum of those who are registered as residents and the temporary migrants, it follows that urban China in 2004 had a population of around 663 million. Of those, 35 percent were rural-born. It is interesting that this percentage is similar to the proportion of people from mainland China in the Hong Kong labour force; this was reported to be 32.6 percent in 1996 (See Zhang et al 2005). It appears that the hukou system of P.R. China has been as efficient in keeping rural migrants out of its cities, as the immigration policy of Hong Kong and emigration policy of mainland China were in keeping people from mainland China out.

\section{/ Table 1 about here /}

/Figure 1 about here /

Table 1 shows the number of permanent migrants in our sample by gender and age. The proportion of males among the permanent migrants is higher than the corresponding proportion among urban born residents; this result probably signals larger access to career routes, as females seldom join the PLA, for example. Nevertheless, the difference is not large. Not surprisingly, few children and young adults in the permanent urban population are ruralborn. Assume that the propensity for being a permanent migrant is constant over time and is highest for young adults and decreases with age. In such a case, one would expect that among adults the proportion of rural-born in the urban population would increase with age. This is not exactly what we find, see Figure 1 . The highest proportion of rural-born (32 percent) is found among those aged 31 to 35, i.e. among persons born 1967-1971. Here we see people 
who reached adulthood in reform China when higher education had expanded and geographical mobility had become easier. The situation for those born in rural China a decade earlier, i.e. those who became adults during the Cultural Revolution, appears to be rather different. As few as 17 percent of urban residents aged 41 to 45 are rural-born.

/Table 2 and Table 3 about here/

We now turn to the question of what characterises cities to which permanent migrants move. For this we use the fact that the urban sample is drawn from 77 different cities and for each we can compute its migration density defined as the fraction of rural-born registered inhabitants. The mean ratio is 0.224 and Table 2 shows that permanent migrants make up a larger proportion of the population in medium and smaller-sized cities than in large cities. This is reasonable as housing availability and other barriers to immigration typically make migration to larger cities more difficult than migration to smaller cities. We also report that the migration density is larger in the middle region of China than in the East or the West. Furthermore, the migration density is related to per capita income of city as well as employment rate. ${ }^{7}$ In Table 2 it can be seen, for example, that low-income cities have a high proportion of permanent migrants. However, low-income cities are also typically small in size; therefore it is more instructive to look at the results from estimating a regression model with migration density as the dependent variable. Table 3 shows that we cannot report a statistically significant relationship between city income and migration density once other city characteristics are included in the model. However, the employment rate of the city is reported to have a statistically significant and positive coefficient, and there are significant coefficients for city size as well as region. This model predicts a migration density for Beijing of 0.112 , while for a small or medium-sized city located in the middle of China, the prediction varies due to variation in the employment rate observed in the sample (from 0.505 to 0.949 ) from 0.173 to 0.381 with the income level set at the sample mean.

\section{From the origin}

In this section we view the permanent migrants from the perspective of origin. For this we derive a sample of rural-born persons by merging the sample of permanent migrants as defined above with persons from the Rural Household Income Survey (“stayers”). Doing this 
assumes that urban to rural migration is non-existent, which is an exaggeration, though probably only slight. When reporting how high a proportion of the rural-born population is comprised of permanent migrants, we consider the fact that the probabilities of being included in the urban and rural samples differ somewhat. ${ }^{8}$

\section{/ Table 4 about here/}

Table 4 provides descriptive statistics for permanent migrants, other rural-born persons and the summary category of rural-born persons. We find that 11.5 percent of the rural-born had become permanent migrants by 2002. Not surprisingly, the table shows that the permanent migrants differed from the stayers in many respects. The only exception is for gender composition which is identical across the groups. Permanent migrants are on average 10 years older than the stayers. There is a smaller fraction of persons belonging to the ethnic minorities among the permanent migrants than in the entire population of rural-born individuals. According to our calculations, only 3 percent of people belonging to an ethnic minority born in rural China have become permanent migrants, which can be compared to 13 percent in the majority population. This large difference can be seen in the light of China's minority population being more concentrated to remote areas; remoteness most probably affects the probability of becoming a permanent migrant.

Given that one route for becoming a permanent migrant is through being a cadre, it is not surprising that as many as one out of three permanent migrants were members of the Communist Party at the time of the survey, while only 1 out of 18 stayers were party members. The difference in education across the two groups is also expected, as a long education is a route to receiving a hukou. While as many as 28 percent of the permanent migrants have at least a college education, the corresponding proportion among stayers is less than 2 percent. Our calculations show that as many as 71 percent of rural-born persons with college diplomas now live in cities as permanent migrants.

The topic of brain drain has been widely discussed regarding international migration from developing to developed countries. In such a context it is typically claimed that the geographical mobility of better-educated workers from the poor countries to the rich countries is harmful for the former and benefits the latter; policy measures are therefore warranted. Our numbers indicate that the internal brain drain in China, from its rural areas to its cities, has 
been great. Yet at present, this issue does not appear to be attracting much attention among observers and policymakers. This is in contrast to earlier epochs in the history of the PRC. Previously, educated youths were sent to the countryside on a small scale. However, this policy of "up to the mountains and down to the villages” was intensified during the Cultural Revolution and as many as 14 million educated young people, for the most part graduates of secondary schools, were sent to the countryside (Beijing Daily, 1998, see also Bernstein, 1977). However, the overwhelming majority of educated youth returned to cities after the end of the Cultural Revolution.

We now ask: What characteristics at the family level of origin affect who has become a permanent migrant in China? This question does not appear to have been addressed earlier. When selecting candidates to be used in the empirical analysis, we have to consider what might affect people using the various routes for receiving a hukou. As there are several different routes, many factors are likely to be in play; factors might differ across location as well as time. However, we are limited by what is recorded in our data. For example, the surveys do not provide information on the precise location where the person spent his or her childhood and youth; we only know that he or she is rural-born. Given this, we use two specifications with a small number of parental characteristics to analyse who becomes a permanent migrant.

From the findings reported above, it is self-evident to include ethnicity in the specification. It is commonly found that parental education affects education of the child, therefore we also include variables measuring parental education in the specification. Further we include, for several reasons, a variable measuring if at least one of the parents was a member of the Communist Party. There might be an intergenerational relation to party membership and party membership helps to urbanization. A parent's party membership might signal better opportunities for receiving a long education or receiving a hukou through other channels. Finally we add gender and in an alternative specification also age and age squared to the explanatory variables.

/Table 5 about here/

When estimating logit models we split the sample by age of person into three subsamples; the results are reported in Table 5. Despite that the probability of becoming a permanent migrant 
differs across cohorts, the process of becoming one appears to be relatively similar across cohorts. Ethnicity as well as parent education strongly affect the probability of becoming a permanent migrant. A parent's CPC membership also affects the probability of becoming a migrant, but not as strongly as education and ethnicity. Coefficients of gender are in most cases estimated with low t-statistics.

\section{/ Table 6 about here/}

Based on the estimates, in Table 6 we show probabilities of becoming a permanent migrant predicted for a few typical individuals who have grown up in families with the same characteristics but were born during different periods. Reading across columns it is found that the older the person, the higher the probability of becoming a permanent migrant. Reading down the columns we find polar opposities. At one extreme is a minority person with loweducated parents who were not CPC members. This person is predicted to have a probability of being a permanent migrant among the oldest cohort of only 4 percent. At the other extreme is a majority person with parents possessing at least a primary school education and who were CPC members. ${ }^{9}$ For this case, the predicted probability of being a permanent migrant among the oldest cohort is 69 percent.

\section{/ Table 7 about here /}

We now compare the economic situation in 2002 for permanent migrants and those rural-born who were left behind, to find out how large the gains are from urbanising. As a rural-born person can urbanize by becoming a temporary migrant or a permanent migrant, we take both alternatives into account. Information on temporary migrants is taken from the survey presented in Section 3. Table 7 shows per capita total income among the three categories: permanent migrants, temporary migrants and rural resident. Per capita income includes not only money income but also income in kind, income of subsistence agriculture (in rural China), and transfers such as pensions; income is recorded net of taxes and is computed for a period of a calendar year. We find that on average, temporary migrants have per capita incomes twice as high as rural residents, while permanent migrants receive an average income roughly three times as high as rural residents. 
The numbers in Table 7 also show that in rural areas, mean per capita income of ethnic minorities is 34 percent lower than for the ethnic majority. However, such differences are much smaller for both categories of migrants. While we have found that ethnicity is a barrier to becoming a permanent migrant, it seems to be of little disadvantage to those who have migrated. The table also shows that CPC members have higher per capita incomes than others, and in a percentage sense this gap is larger for rural residents than for the two types of migrants.

Finally, turning to education we find the more or less universal positive relation between education and income in all three categories. Among adult permanent migrants, per capita income increases profoundly by age up to $46-50$ after which differences by age are small. For the two categories of migrants the age/income relation is weaker. This means that the mover/stayer income gap depends on the age of the person. It is smallest for young adults and highest at mature middle-age. Differences in personal characteristics between the migrants and the stayers must contribute to the mover /stayer income gap. How important is the contribution?

To answer this question we perform the following exercise: First we define 10 sub-samples of adults of specific ages and pool rural stayers, temporary migrants and permanent migrants of a particular age. In the first specification we regress per capita income on a dummy indicating if the individual is a temporary migrant and another if he or she is a permanent migrant. In this way the constant expresses the mean income of stayers in a particular age category. In the second specification we add to the explanatory variables the schooling years of the individual as well as a dummy indicating CPC membership of the individual. The parameter estimates for the variables temporary migrant and permanent migrant are also shown in Figure 2a, and indicate the adjusted mover/stayer income gap. Figure $2 \mathrm{~b}$ reports ratios of the income of temporary and permanent migrants to that of stayers. Comparing the age/income profiles derived from the two specifications provides further insights. ${ }^{10}$

/Figures 2a and 2b about here/

A first perception is that the longer education and the larger proportion of party members among the permanent migrants actually contribute to the migrant/stayer income gap. However, such differences serve only to explain a relatively small proportion of the income 
gap. Second, there are large incentives to urbanize, as given education and party membership status, temporary as well as permanent migrants have much higher per capita incomes. Third, there are incentives for receiving a hukou for temporary migrants intending to stay at the urban destination. This is evident by the adjusted curves for permanent migrants being higher than for temporary migrants for persons aged 30 and older. Note also that among temporary migrants the adjusted migrant/stayer income gap is rather similar to the unadjusted gap, reflecting that temporary migrants and rural stayers on average do not differ regarding education and party membership.

From the estimates we can report the economic value of receiving a hukou as the difference in earnings between temporary and permanent migrants computed over the age-span 30-60 (assuming the profiles remain unchanged). If we apply a discount rate of 5 percent, the sum is 79982 Yuan, while the annual wage income in urban China in 2002 is 12422 yuan. The full economic benefit of a hukou also includes better access to social services for the worker and his/her family, and higher pension payments when retired. It is interesting to compare the average earnings benefit for receiving a hukou (according to our calculations) with prices rural residents actually have paid. Chan (2004) summarizes such information from the beginning of the 1990s. It is reported, for example, that the price of a hukou in central Shanghai was 81457 Yuan (in 2002 prices) while the price in a suburban district was 40729 Yuan and 20364 Yuan in a suburban county. The same author also reports that in the first half of July 1992, 40000 hukou were sold in Henan province alone at prices ranging from 11249 Yuan to 56247 Yuan (in 2002 prices). It thus appears that local governments have set the price of a hukou, signifying that they on average share the economic value with rural residents.

\section{At the destination}

/Table 8 about here/

In this section and the next we change perspective and study how permanent migrants are faring at the destination by concentrating on earnings among persons of work active ages (aged 16-60). For this purpose we first compare the permanent migrants with urban-born residents in Table 8 . There are both similarities and differences between the two categories. 
Starting with the former we report an average length of education of 11 years, although the education levels are somewhat more varied among the permanent migrants. By inspecting the education level of the parents we see that in the space of one generation the educational level has increased rapidly. One quarter of the urban-born residents and one-third of the rural-born had a father who was illiterate; as many as half of the urban-born and two-thirds of the ruralborn had an illiterate mother. While there was a profound gender difference in education for the parent generation (average schooling of fathers was 5.3 years compared to 4.1 years for mothers), somewhat less of a difference is observed in the present economically active generation (average schooling of males is 11.4 years compared to 10.8 years for females).

The ethnic composition is rather similar for rural and urban-born urban residents, which means that ethnic minorities make up a considerably smaller proportion of urban residents than in China' s total population. Permanent migrants are on average two years older than the urban-born residents and somewhat related to this, a higher number of permanent migrants are married. Given that CPC membership facilitates the conversion of hukou status, it is not surprising that a larger proportion of permanent migrant are party members than for the urban-born. Fewer permanent migrants are students than urban-born. Turning to the focus of this paper, we find that while 65 percent of the urban-born residents are employed or selfemployed, the corresponding proportion among permanent migrants is 73 percent, a difference of 8 percentage points. We now investigate if this difference can be attributed to individual characteristics in addition to permanent migrants and urban-born residents having different spatial distributions.

\section{/Table 9 about here/}

We analyse determinants of employment by estimating Logit-models for the sample of all urban residents. Explanatory variables measure years of schooling, marital status, political status, ethnicity, age, as well as a dummy indicating if the person is a permanent migrant or not. The specification also includes 76 dummies for cities. We estimate models for both genders combined, but also for each gender separately. As expected, the estimates show employment to be positively affected by education, by being a member of CPC and among males by being married, while for females the status of being married has a negative effect. The coefficients of ethnicity are all estimated with a low t-statistic. Turning to our focus for the analysis, the coefficients for being a permanent migrant are all positive and highly 
significant. Figure 3 predicts the probability of being employed for a typical male and female but with varying age and status as permanent migrant or urban born resident. The probabilities of working for permanent migrants and male are higher than that of urban residents and female, respectively. The difference in the probability to work between male and female decreases first with age and increases again when approaching retirement. This is also the case for the difference in the probability of working of permanent migrants and urban residents.

/Figure 3 about here/

The rest of the analysis in this section is made for people who are working. Table 8 shows no difference in mean earnings between permanent migrants and urban-born residents. We proceed by running log earnings-functions using different specifications. Common to the specifications are variables measuring schooling, marital status, CPC membership and ethnicity. We also include dummies for city of residence as it was found that permanent migrants disproportionately reside in cities with a low per-capita income. We present estimates for the pooled sample of permanent migrants and urban residents, males and females combined, for each gender and include a dummy for being a permanent migrant. We also present results for the sub-samples permanent migrants and urban residents separately. For the former category we also work with different sub-samples and specifications.

\section{/Table 10 abut here/}

The estimated rates of return to education presented in Table 10 are somewhat higher for females than for males but do not differ between permanent migrants and other urban residents. For example, the rate of return for one year of schooling is 7 percent for males and 9 percent for females. Though different from what was reported from earnings functions estimated based on older data for China, these numbers are in international comparison not particularly low; they reflect the situation that economic returns to schooling in urban China increased during the years preceding collection of the survey we are working with (See Zhang et al, 2005). As previously found when running an earnings-function for China, there is a positive effect of being a CPC member (although the interpretation of this is not self-evident), and a positive effect of being male. There is no indication in our estimates that ethnicity affects earnings among urban workers. 
When we pool permanent migrant and urban residents, we obtain a positive effect of being a permanent migrant estimated with a high t-statistic in the sample of men amounting to 8 percent. However, the corresponding positive coefficient for females is lower and estimated with a low t-statistic. For both genders we report positive coefficients for the variable years since receiving a hukou that are estimated with high t-statistics. We also report negative coefficients for the variable years since receiving hukou squared, and for males the coefficient is estimated with a high t-statistic.

Based on the estimates, we predict earnings for a typical urban-born male and a typical urban born female, from age 16 up to the general retirement age (60 years for men and 55 for women). We also predict earnings for permanent migrants with the same characteristics but with hukous received at different ages as shown in Figure 4. In short, age when receiving a hukou matters. We find that permanent migrants who receive a hukou after age 25 never catch up with their urban-born counterparts. For the women, the earnings gap is substantial and considerably larger than the corresponding gap for men. This gender difference might be due to reasons for receiving hukou after age 25 differ between men and women. Family unification is probably a more frequent reason for females while career path is more frequent for males.

\section{/Figure 4 about here/}

In contrast to what we found for women receiving a hukou after age 25 , receiving a hukou at an earlier age is predicted to lead to permanent migrants overtake urban-born. For example at age 40, those female permanent migrants who received a hukou between age 21 and 25 are predicted to earn 7 percent more than their urban-born counterparts. For men who receive a hukou before age 25 the situation is still better; they are actually predicted to have earnings considerably higher than their urban-born counterpart. For example men who receive a hukou between age 21 and 25 are predicted to earn 16 percent more than their urban-born counterparts at age 40 .

Our result that age when receiving a hukou is important for labour market assimilation is consistent with what Liu (2005) reports based on data for 1995. What is new is the evidence of gender differences. We carry this issue further and ask if it is possible to show that gender 
differences during working life also signify differences after retirement, as in urban China pensions are related to a person's earnings history. We therefore examine pensions for people over age 60 and estimate simple regression models including age as independent variable. The OLS estimates are reported in Appendix 2. Not surprisingly, we find that males receive higher pensions than females. When splitting the sample by gender we find a positive coefficient for permanent migrants among males estimated with a high t-value, but for females the t-value is low. It is interesting to see that when we include a dummy that indicates if the person is retired from government or a similar institution, this has a large positive effect on the pension. However, the coefficient for being a permanent migrant is still positive and estimated with a high t-value for men (while it is negative for females).

The material presented in this section has shown that permanent migrants are more likely to work than their urban-born counterparts. For those who work, the results indicate that permanent migrants who receive a hukou before age 25 years are economically wellassimilated into the labour market at the destination, and actually tend to earn more than their urban-born peers. Such a positive selection of rural people moving into cities is perhaps not unique to present-day China; see Hatton and Bailey (2002) who studied male workers born in rural Great Britain who migrated to London in 1929-1931. Their earnings functions show a positive effect of being rural-born that is of the same magnitude as we here have reported for permanent migrants. ${ }^{11}$

\section{Different routes for receiving a hukou and success in the labour market}

Up to now we have not differentiated between kinds of routes used by rural-born persons for acquiring a hukou. This section investigates to what extent such a differentiation is informative, taking into account that the urban labour market in China is characterised as being highly segregated. We will distinguish between career routes on one hand and on other more recent routes such as compensation for land acquisition, house purchase or direct hukou purchase. Career routes typically apply to a person working in a better segment of the labour market (as a white-collar worker), while this is not necessarily the case for people who receive a hukou via the more recent routes. 
In the urban survey we examine respondents who had urbanized who were asked how they received their hukou. Among workers aged 16-60, 1117 indicated that they had received their hukou through career routes, while 219 received it through informal routes. ${ }^{12}$ We define white-collar to mean occupations coded as professional, director, director of department, clerical/ office staff. Table 11 shows that not less than 82 percent of those who had received a hukou through career routes were occupied in white-collar occupations, to be compared with only 29 percent among those who had received a hukou through other channels.

\section{/Table 11 about here/}

Permanent migrants who have received a hukou through career routes are more likely to be male, members of the Communist Party, have a longer education and have lived in urban China longer than those who have received hukou through informal routes. There is also a considerable difference in earnings across the two categories, as mean income of migrants who received a hukou through informal routes on average earn 26 percent less than those who received a hukou via career routes. To what extent can this earnings difference be attributed to the occupational segregation across the two categories?

Using the method proposed by Brown et al. (1980) and Liu et al. (2004), we can decompose the earnings differentials among permanent migrants through different routes to get hukou into four parts. Assume the earnings functions are:

$$
\begin{aligned}
& \ln Y_{j}^{f}=X_{j}^{f} \beta_{j}^{f}+\varepsilon_{j}^{f} \\
& \ln Y_{j}^{i}=X_{j}^{i} \beta_{j}^{i}+\varepsilon_{j}^{i}
\end{aligned}
$$

where superscripts $\mathrm{f}$ and i represent permanent migrants who received a urban hukou through formal and informal routes, respectively. Subscripts $j=1,2$ represent white- and blue-collar occupations, respectively. $X_{j}$ is a list of variables determining earnings such as age, schooling, gender, etc. and $\beta_{j}$ are parameters to be estimated.

The earnings differential can be decomposed as four parts: 
$\overline{\ln Y^{f}}-\overline{\ln Y^{i}}=\sum_{j=1}^{2} P_{j}^{i} \hat{\beta}_{j}^{f}\left(\bar{X}_{j}^{f}-\bar{X}_{j}^{i}\right)+\sum_{j=1}^{2} P_{j}^{i} \bar{X}_{j}^{i}\left(\hat{\beta}_{j}^{f}-\hat{\beta}_{j}^{i}\right)+\sum_{j=1}^{2} \overline{\ln Y^{f}}\left(P_{j}^{f}-\hat{P}_{j}^{i}\right)+\sum_{j=1}^{2} \overline{\ln Y^{f}}\left(\hat{P}_{j}^{i}-P_{j}^{i}\right)$

where $\hat{P}_{j}^{i}$ is what the proportion of permanent migrants receiving an urban hukou through informal ways would be in occupation $\mathrm{j}$ had they been treated equally with their counterparts getting a hukou through formal ways. The four parts can be named intra-occupational explained, intra-occupational unexplained, inter-occupational explained and interoccupational unexplained, respectively.

This framework is suitable for our purpose as it enables us to investigate to what extent allocation into occupation by routes for receiving a hukou contributes to the earnings differential between those who received a hukou via career routes and other routes into explained and unexplained parts. Further the intra-occupational part indicates to what extent persons who have received a hukou via different routes receive different rewards given their occupation. A limitation in our application is that our data forces us to work with only two occupations, which might have consequences on how large a proportion of the difference will be found to be unexplained.

When applying this framework we estimate a probit model of occupational attainment as well as earnings functions for each occupation for the two categories of permanent migrants separately. The results are found in Appendix 3 of the paper where it is shown that schooling and membership in CPC are important determinants of occupational attainment for both categories of permanent migrants, while age and age squared are significant in the equation explaining occupation only among permanent migrants who entered urban China through career routes.

\section{/Table 12 about here/}

The results from the exercise are reported in Table 12. We find that 40 percent of the difference in earnings across the two categories of rural-born people who have migrated to urban China via different routes can be explained by persons being occupied in different sectors; thus 60 percent is due to differences within sectors. Further, half of the differential can be attributed to differences in variables, while the other half is unexplained. The intraoccupational part (35 percent of the total earnings differential) is larger than the inter- 
occupational part (16 percent of the total earnings differential). This means that unequal treatment within occupations is more serious than unequal access to occupations. This is in contrast to the explained parts in the intra-occupational and inter-occupational parts being of rather similar size. Thus income differentials explained by characteristics are of the same magnitude within and between occupations.

This section has shown that earnings of permanent migrants to urban settings differ by routes of receiving a hukou. People who have entered via career routes earn considerably more than others. About half of this difference can be explained by differences in variables, half by different treatment in the urban setting. There are signs of different access to the better segments of the labour market, but at least as important are different treatments within the broad occupations we specified.

\section{Conclusions}

In this paper we have studied people born in rural China who now live in urban areas of China and possess a residence permit, a hukou. We have used large datasets covering large parts of China in 2002. The number of permanent migrants has been estimated and portrayed. The permanent migrants have been compared to the rural-born peers they left behind as well as to migrants who live temporarily in urban China without a hukou. Furthermore, the permanent migrants have also been compared with their peers at the destination.

According to our estimates, permanent migrants numbered around 110 million persons and constituted 20 percent of the registered population of China's urban areas. This means that they are as numerous as the temporary migrants living in China's urban areas, a category which has received more attention than the permanent migrants. The proportion of rural-born persons is high for those who reached adulthood in reform China and lower for those who became adults during the Cultural Revolution. The permanent migrants are disproportionately located in small cities, cities with high employment and cities located in the middle region of China. 
Compared to their rural-born peers, permanent migrants have much higher per-capita incomes than their peers (rural-born persons left behind). A longer education and a higher proportion of membership in the Communist Party contribute to this difference but most of the difference remains unexplained, signalling large incentives to urbanise as well as to receive a hukou. We have also reported that other rural-born persons who have moved to urban China without a hukou have much higher incomes than the rural-born persons left behind in the villages. However, these temporary migrants are not as advantaged as the permanent migrants and they have substantial incentives for procuring a hukou.

While living a life very different from their peers left behind, the economic circumstances of permanent migrants at the destination are on average similar to the urban-born population. The permanent migrants were actually found to have a higher probability of working. Permanent migrants who received a hukou before age 25 do well in the labour market and we have reported indications that they actually overtake urban-born peers regarding earnings. After age 60, permanent male migrants receive higher pensions than their urban-born counterparts. In contrast, permanent migrants who receive a hukou after age 25 never catch up with their urban-born counterparts; for such females the earnings gap to urban-born residents is substantial.

It was found meaningful to distinguish between career routes for receiving a hukou through education, becoming a cadre, being an officer of the People's Liberation Army, and more recent routes. More often than for other routes, career routes lead to a job in the better segment of the urban labour market and to higher earnings. To some extent, the higher earnings among migrants who have entered urban China through career routes can be attributed to variables at the personal level. However, there are also signs of unequal treatment between different categories of permanent migrants within occupations and to a smaller degree in access to better occupations.

We will round off this paper with some comments on China's policy of requiring rural-born persons desiring to live in urban China to have a hukou. At present there are many discussions of policy changes. When following these discussions one should understand that much of the policymaking on this issue is made at the city level. This means that at the moment there is great variation in the requirements for receiving a hukou across cities. An observer knowledgeable of the situation in one city, cannot be certain that this knowledge will apply to 
another city. Such local variation has advantages, but also disadvantages. Among advantages there can be local experiments that produce valuable knowledge. As to disadvantages, local requirements might prevent a fully developed labour market from being established. For example, if a person living in one of the larger cities is offered a better job in a smaller city, he or she has to weigh the higher compensation against the risk of losing a more attractive hukou.

Our study has shown that the vast majority of rural-born persons who have received a college diploma now live in urban China. There has thus been a large internal brain drain in China from its disadvantaged rural areas to its more thriving urban areas. From this perspective China's hukou system has similarities to patterns of the immigration policies industrialised countries pursue. They welcome immigrants who can contribute to the country in the new location, while they keep others out.

Like industrialised countries in the West, urban China faces the great challenge of being attractive among a large population of non-residents. However, while in western countries such people are not citizens, in urban China those facing barriers are citizens but not holders of residence permits. How to handle the issue of urban residence permits is, and will continue to be, a great challenge for policymakers in China. The difficulty is compounded by the fact that China's cities already have large populations of non-residents. If such persons do not receive rights more similar to a hukou, the situation will lead to pressing social tensions. However, making it easier to receive a hukou or even abolishing the requirement, would most probably lead to a rapid influx of a larger number of migrants, which in turn will lead to increased social tensions. 


\section{References}

Alexander, Peter and Chan, Anita (2004) “Does China Have an Apartheid Pass System?”, Journal of Ethnic and Migration Studies, 30 (4) 609 - 629.

Beijing Daily (1998) “Educated Youth to the Countryside”, July 26, 1998.

Bernstein, Thomas P. (1977) Urban Youth in the Countryside: Problems of Adaptation and Remedies, China Quarterly, No. 69, pp. 75-108.

Bonnin, Michel, (2005), "Shangshan Xiaxiang Yundong Zaipingjia” (“A Historical Assessment of the "Up to the Mountains, Down to the Villages" Movement"), Shehuixue Yanjiu (Sociological Research), No. 5, pp. 154-181, in Chinese.

Brown, Radall S., Moon, Marilyn, and Zoloth, Barbara S., (1980), "Incorporating Occupational Attainment in Studies of Male-Female Earnings Differentials”, Journal of Human Resources, 15, 1:3-28.

Cai Fang, Du Yang and Wang Meiyan, (2001), The hukou System and Protection of Labor Market , Jingji Yanjiu (Economic Research), vol. 12, in Chinese.

Cai, Fang, Du Yang and Wang Meiyan, (2003), The Political Economy of Labor Migration, Shanghai Sanlian Press and Shanghai People's Press.

Chan, Kam King, (1994), Cities with Invisible Walls, Hong Kong: Oxford University Press.

Chan, Kam Wing, (2004), The Reform of the hukou System and Rural-Urban Migration, China Labor Economics, Vol. 1, pp.108-123, in Chinese.

Chan, Kam Wing and Li Zhang, (1999), “The Hukou System and Rural - Urban Migration in China: Processes and Changes”, China Quarterly, 160: 818 - 855.

Cheng, Tiejun and Selden, Mark (1994), “The Origins and Social Consequences of China's Hukou System” China Quarterly, 139: $644-668$.

Hatton, Timothy, J. and Bailey, Roy, E. ( 2002) "Natives and Migrants in the London Labour Market, 1929 - 1931”, Journal of Population Economics, 15 (1) 59 - 81.

Knight, John and Song, Lina (1999) The Rural - Urban Divide. Economic Disparities and Interactions in China, Oxford: Oxford University Press.

Li, Shi, (1997), Modelling Labor Migration during China’s Economic Transition, Jingji Yanjiu (Economic Research), vol 1, in Chinese.

Li, Shi, Luo Chuliang, Wei Zhong and Yue Ximing, (2006), “Appendix-The 1995 and 2002 Household Surveys: Sampling Methods and Data Description”, in Gustafsson, Li and Sicular eds., Inequality and Public Policy, Cambridge University Press, forthcoming. 
Liang, Zai and Ma, Zhongdong (2004) "China's Floating Population: Evidence from the 2000 Census”, Population and Development Review, 30 (3) 467 - 488.

Liu, Zhiqiang (2005) "Institution and Inequality: The Hukou System in China”, Journal of Comparative Economics, 33, 133 - 157.

Liu, Pak-Wai, Zhang, Junsen, Chong, Shu-Chuen (2004) “Occupational Segregation and Wage Differentials between Natives and Immigrants: Evidence from Hong Kong”, Journal of Development Economics, 73, 395 - 413.

Lu, Yilong, (2002), The hukou System in China since 1949: Structure and Change, Beijing Daxue Xuebao(Academic Journal of Peking University), No. 2.

Meng, Xin and Zhang, Junsen (2001) “The Two-Tier Labour Market in Urban China. Occupational Segregation and Wage Differentials between Urban Residents and Rural Migrants in Shanghai”, Journal of Comparative Economics, 29, 485 - 504.

NBS (National Bureau of Statistics), (2005), China Statistical Yearbook, Beijing: China Statistical Press.

Research Division of State Council, (2006), General Report on Migrant Workers, Survey Report on Migrant Workers in China, China Yanshi Press.

Solinger, Dorothy J., (1999), Citizenship Issues in China's Internal Migration: Comparisons with Germany and Japan, Political Science Quarterly, Vol. 114, No. 3: 455-78.

United Nations Development Program (UNDP) (2005), China Human Development Report, 2005.

Wang, Fei -Ling (2004) "Reformed Migration Control and New Targeted People: China's Hukou System in the 2000s”, China Quarterly, 177: 115 - 132.

Wang, F. and Zuo, X. (1999), “Inside China’s Cities: Institutional Barriers and Opportunities for Urban Migrants”, American Economic Review, 89 (2) 276 - 280.

Wong, Linda and Huen Wai-Po, (1998), Reforming the Household Registration System: A Preliminary Glimpse of the Blue Chop Household Registration System in Shanghai and Shenzhen, International Migration Review, Vol. 32, No. 4, pp. 974-994.

Wu, Xiaogang and Treiman, Donald, J (2004) “The Household Registration System and Social Stratification in China: 1955 - 1996”, Demography, 41 (2), 363 - 384.

Yang, Dennis Tao and Hao Zhou, (1999), Rural-Urban Disparity and Sectoral Labor Allocation in China, Journal of Development Studies, 35 (3), 105-133.

Zhang, Junsen, Zhao, Yaohui, Park, Albert and Song, Xiaoqing, (2005) "Economic Returns to Schooling in Urban China”, Journal of Comparative Economics, 33, 730 - 752.

Zhang, Qingwu, (1983), Hukou Dengji Changshi (Brief Introduction on hukou Registration), Beijing: Law Press. 
Zhao, Renwei and Li Shi, (1999), “Zhongguo Jumin Shouru Chaju de Kuoda jiqi Yuanyi” (The Rising Income Inequality in China and its Causes), In Zhao Renwei, Li Shi and Carl Riskin eds. Re-study on Income Distribution of Chinese Households, pp. 42-71, Beijing: China Financial and Economic Publishing House.

Zhao, Yaohui, (2000), Rural-to-Urban Labor Migration in China: The Past and the Present, in Rural Labor Flows in China, eds. Loraine A. West and Yaohui Zhao, Institute of East Asian Studies, University of California, Berkeley.

Zhao, Yaohui, and Liu Qiming, (1997), Studies on the History of Rural-Urban Migration in China: 1949-1985, Chinese Journal of Population Science, No. 2, pp. 26-35, in Chinese. 
Table 1. Urban Residents and Permanent Migrants by gender and age group

\begin{tabular}{lrrrr}
\hline & \multicolumn{2}{c}{ Urban Residents } & \multicolumn{2}{c}{ Permanent Migrants } \\
\cline { 2 - 5 } & $\%$ & $\begin{array}{c}\text { Number of } \\
\text { observations }\end{array}$ & $\%$ & $\begin{array}{c}\text { Number of } \\
\text { observations }\end{array}$ \\
\hline Gender & \multicolumn{5}{c}{ \% } & & \\
\hline Male & 48.94 & 7836 & 47.35 & 2130 \\
Female & 51.06 & 8177 & & 1939 \\
Age group & & & & \\
$<16$ & 16.82 & 2694 & 5.58 & 227 \\
$16-20$ & 7.94 & 1271 & 3.10 & 126 \\
$21-25$ & 5.96 & 954 & 3.51 & 143 \\
$26-30$ & 4.71 & 755 & 6.51 & 265 \\
$31-35$ & 7.10 & 1137 & 13.05 & 531 \\
$36-40$ & 10.74 & 1719 & 13.86 & 564 \\
$41-45$ & 10.79 & 1728 & 8.90 & 362 \\
$46-50$ & 13.17 & 2109 & 12.36 & 503 \\
$51-55$ & 8.92 & 1429 & 10.74 & 437 \\
$56-60$ & 4.38 & 701 & 7.54 & 307 \\
$60+$ & 9.47 & 1516 & 14.84 & 604 \\
& & & & \\
Number of & & 16013 & & 4069 \\
observations & & &
\end{tabular}

Table 2. Permanent Migrants as Proportion of Urban Residents in Different Types of Cities

\begin{tabular}{lcc}
\hline \multicolumn{1}{c}{ Characteristic of city } & Ratio & No. of Cities \\
\hline Per capita Income & & \\
$<8000$ & 0.274 & 26 \\
$8000-10000$ & 0.239 & 28 \\
$10000-12000$ & 0.150 & 10 \\
$>12000$ & 0.145 & 13 \\
& & \\
Employment Rate & 0.181 & 7 \\
$<0.65$ & 0.175 & 15 \\
$0.65-0.70$ & 0.189 & 15 \\
$0.70-0.75$ & 0.246 & 21 \\
$0.75-0.80$ & 0.280 & 19 \\
$>0.80$ & & \\
City size & 0.136 & 20 \\
Large & 0.254 & 57 \\
Small or Medium & & \\
& & 30 \\
Region & 0.163 & 28 \\
Eastern China & 0.284 & 19 \\
Middle China & 0.231 & 77 \\
Western China & & \\
& 0.224 & \\
Total & & \\
\hline
\end{tabular}


Table 3. Determinants of Migration Density at the City Level

\begin{tabular}{lc}
\hline \multicolumn{1}{c}{ Explanatory variables } & \\
\hline Employment Rate & $0.468^{* *}$ \\
& $(0.197)$ \\
Small and medium sized & \\
cities (Reference) & \\
Large Cities & $-0.067^{*}$ \\
Eastern China & $(0.039)$ \\
Middle China & $-0.080^{*}$ \\
(Reference) & $0.043)$ \\
& \\
Western China & \\
& \\
Per Capita Income & -0.056 \\
& $(0.039)$ \\
Constant & -0.008 \\
& $(0.006)$ \\
Adjusted R & 0.010 \\
Number of observations & $(0.140)$ \\
\hline
\end{tabular}

Notes: 1) Standard errors in parenthesis. ${ }^{* * *}, * *, *$ denote statistically significance from zero at .01, .05 and .1 levels, respectively. 2) The dependent variable is defined as the ratio of permanent migrants to the total population with hukou (including permanent migrants) in the city. 
Table 4. Permanent Migrants, Rural Residents and Rural Born by Household Characteristics.

\begin{tabular}{|c|c|c|c|c|}
\hline $\begin{array}{c}\text { Individual } \\
\text { Characteristics }\end{array}$ & $\begin{array}{l}\text { Permanent } \\
\text { Migrants }\end{array}$ & Rural Residents & $\begin{array}{l}\text { Rural Born } \\
\text { Persons = } \\
\text { Rural Residents + } \\
\text { Permanent } \\
\text { Migrants }\end{array}$ & $\begin{array}{l}\text { Proportion of } \\
\text { Permanent } \\
\text { Migrants } \\
\text { among Rural } \\
\text { Born } \\
\text { (percent) }\end{array}$ \\
\hline \multicolumn{5}{|l|}{ Gender } \\
\hline Male (\%) & 52.10 & 52.02 & 52.06 & 11.52 \\
\hline Female & 47.90 & 47.98 & 47.94 & 11.49 \\
\hline \multicolumn{5}{|l|}{ Ethnicity } \\
\hline Ethnic Minority (\%) & 3.75 & 13.96 & 8.86 & 3.37 \\
\hline Han & 96.25 & 86.04 & 91.15 & 12.70 \\
\hline \multicolumn{5}{|l|}{ Political Status } \\
\hline CPC Member (\%) & 32.85 & 5.67 & 19.26 & 42.98 \\
\hline Not CPC Member & 67.15 & 94.33 & 80.74 & 8.47 \\
\hline \multicolumn{5}{|l|}{ Age (\%) } \\
\hline$<16$ & 5.37 & 20.72 & 13.05 & 3.26 \\
\hline $16-20$ & 2.98 & 11.69 & 7.34 & 3.21 \\
\hline $21-25$ & 3.54 & 8.85 & 6.20 & 4.95 \\
\hline $26-30$ & 6.42 & 6.72 & 6.57 & 11.05 \\
\hline $31-35$ & 12.98 & 7.48 & 10.23 & 18.42 \\
\hline $36-40$ & 13.85 & 9.24 & 11.55 & 16.31 \\
\hline $41-45$ & 8.95 & 7.10 & 8.03 & 14.09 \\
\hline $46-50$ & 12.42 & 8.96 & 10.69 & 15.27 \\
\hline $51-55$ & 10.84 & 7.29 & 9.07 & 16.20 \\
\hline $56-60$ & 7.74 & 4.65 & 6.20 & 17.78 \\
\hline $60+$ & 14.91 & 7.29 & 11.10 & 20.01 \\
\hline \multicolumn{5}{|l|}{ Education Level (\%) } \\
\hline $\begin{array}{l}\text { Primary School and } \\
\text { Below }\end{array}$ & 14.47 & 43.38 & 28.93 & 4.26 \\
\hline Junior High School & 25.77 & 42.02 & 33.90 & 7.55 \\
\hline Senior High School & 19.49 & 9.90 & 14.70 & 20.77 \\
\hline Technical School & 12.49 & 3.22 & 7.86 & 34.08 \\
\hline College and Above & 27.78 & 1.49 & 14.64 & 71.31 \\
\hline Mean Age & 43.45 & 33.04 & 34.24 & \\
\hline Mean Schooling & 10.10 & 6.61 & 7.04 & \\
\hline $\begin{array}{l}\text { Number of } \\
\text { observations }\end{array}$ & 4937 & 37969 & 42096 & 11.51 \\
\hline
\end{tabular}

Note: The estimate of the proportion permanent migrants among rural-born is obtained by weighting the urban sample and the rural sample using information on population rates from NBS.

The sample of permanent migrants has been expanded to 4937 through random sampling. Before random sampling, the observation of permanent migrants is 4069 . 
Table 5. Estimates of Logistic / Probability Model Explaining Permanent Migration

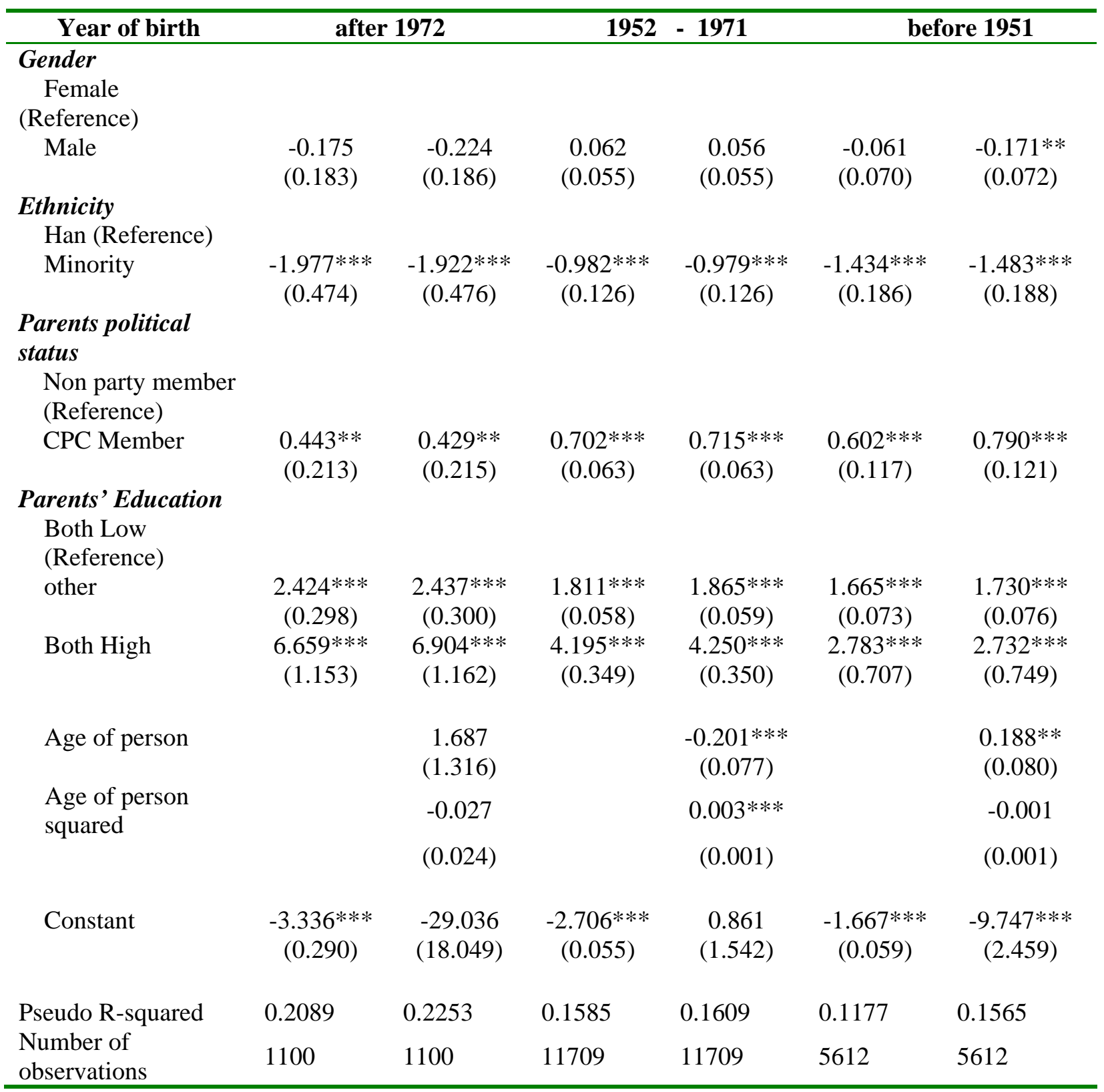

Note ) Education both high: Both parents received the education of senior high school and above. other: other cases

Education both low: Both parents' education levels are below Primary School.

Parental political status: at least one parent with CPC membership vs. other cases 
Table 6. Predicted Probability of being a Permanent Migrant.

\begin{tabular}{lccc}
\hline Charateristics / Birth cohort & $\mathbf{1 9 7 2}$ - & $\mathbf{1 9 5 2 - 1 9 7 1}$ & $\mathbf{- 1 9 5 1}$ \\
\hline $\begin{array}{l}\text { Majority, parents not CPC, } \\
\text { education low }\end{array}$ & 0.032 & 0.064 & 0.154 \\
$\begin{array}{l}\text { Minority, parents not CPC, } \\
\text { education low }\end{array}$ & 0.005 & 0.025 & 0.042 \\
$\begin{array}{l}\text { Majority, parents not CPC, } \\
\text { education middle }\end{array}$ & 0.274 & 0.297 & 0.490 \\
$\begin{array}{l}\text { Majority, parents CPC, } \\
\text { education low }\end{array}$ & 0.049 & 0.123 & 0.250 \\
$\begin{array}{l}\text { Majority, parents CPC, } \\
\text { education middle }\end{array}$ & 0.363 & 0.460 & 0.689 \\
$\begin{array}{l}\text { Proportion permanent migrant } \\
\text { in birth cohort }\end{array}$ & 0.173 & 0.159 & 0.223 \\
\hline
\end{tabular}

Note: Predictions based on estimates reported in Table 5 (Specification 1). 
Table 7. Per Capita Income by Population Categories (Yuan per year)

\begin{tabular}{|c|c|c|c|}
\hline & Permanent Migrants & $\begin{array}{l}\text { Temporary } \\
\text { Migrants }\end{array}$ & Rural Residents \\
\hline \multicolumn{4}{|l|}{ Gender } \\
\hline Male & 9585 & 6619 & 3442 \\
\hline Female & 9234 & 6312 & 3400 \\
\hline \multicolumn{4}{|l|}{ Ethnicity } \\
\hline Han & 10375 & 6705 & 3581 \\
\hline Minority & 9380 & 6446 & 2374 \\
\hline \multicolumn{4}{|l|}{ Political status } \\
\hline CPC Member & 11252 & 6624 & 4509 \\
\hline Not CPC member & 8443 & 6464 & 3338 \\
\hline \multicolumn{4}{|l|}{ Age group } \\
\hline $16-20$ & 6911 & 5856 & 3247 \\
\hline $21-25$ & 7773 & 6592 & 3414 \\
\hline $26-30$ & 8446 & 6621 & 3115 \\
\hline 31-35 & 8819 & 6377 & 3210 \\
\hline $36-40$ & 8816 & 6525 & 3285 \\
\hline $41-45$ & 8941 & 6876 & 3770 \\
\hline $46-50$ & 10020 & 6562 & 3703 \\
\hline $51-55$ & 10564 & 6523 & 3791 \\
\hline $56-60$ & 10965 & 6016 & 3565 \\
\hline $60+$ & 10010 & 4974 & 3238 \\
\hline \multicolumn{4}{|l|}{ Education Level } \\
\hline $\begin{array}{l}\text { Primary school and } \\
\text { below }\end{array}$ & 7648 & 5144 & 3061 \\
\hline Junior high school & 8206 & 6781 & 3413 \\
\hline Senior high school & 8735 & 7131 & 3932 \\
\hline Technical school & 10192 & 7146 & 4735 \\
\hline College and above & 11333 & 9690 & 5337 \\
\hline Total Sample & 9417 & 6469 & 3422 \\
\hline Number of observations & 3842 & 4084 & 30100 \\
\hline
\end{tabular}


Table 8. Urban-born Residents and Permanent Migrants by Individual Characteristics. People aged 16-60

\begin{tabular}{|c|c|c|c|c|}
\hline & \multicolumn{2}{|c|}{ Urban-born Residents } & \multicolumn{2}{|c|}{ Permanent Migrants } \\
\hline & $\%$ & $\begin{array}{c}\text { Number of } \\
\text { observations }\end{array}$ & $\%$ & $\begin{array}{c}\text { Number of } \\
\text { observations }\end{array}$ \\
\hline \multicolumn{5}{|l|}{ Education Level } \\
\hline Primary School and Below & 4.12 & 483 & 7.51 & 243 \\
\hline Junior High School & 26.90 & 3154 & 25.57 & 827 \\
\hline Senior High School & 31.60 & 3706 & 21.68 & 701 \\
\hline Technical School & 10.99 & 1289 & 13.23 & 428 \\
\hline College and Above & 26.39 & 3094 & 32.00 & 1035 \\
\hline \multicolumn{5}{|l|}{ Ethnicity } \\
\hline Han & 95.53 & 11233 & 96.14 & 3112 \\
\hline Minority & 4.47 & 525 & 3.86 & 125 \\
\hline \multicolumn{5}{|l|}{ Marital status } \\
\hline With Spouse & 77.41 & 8958 & 89.16 & 2871 \\
\hline Other Marriage Status & 22.59 & 2614 & 10.84 & 349 \\
\hline \multicolumn{5}{|l|}{ Political status } \\
\hline CPC Member & 21.56 & 2485 & 33.46 & 1065 \\
\hline Other Political Status & 78.44 & 9041 & 66.54 & 2118 \\
\hline Employed & 64.89 & 7618 & 73.48 & 2377 \\
\hline $\begin{array}{l}\text { Non-employed } \\
\text { of which, }\end{array}$ & 35.11 & 4121 & 26.51 & 858 \\
\hline Retired & 11.06 & 1298 & 9.82 & 318 \\
\hline Students & 11.51 & 1352 & 3.86 & 125 \\
\hline Housewives & 1.51 & 177 & 3.80 & 123 \\
\hline Unemployed & 10.56 & 1239 & 8.28 & 268 \\
\hline others & 0.47 & 55 & 0.74 & 24 \\
\hline \multicolumn{5}{|l|}{ Father's Education } \\
\hline Illiteracy & 24.98 & 2107 & 33.98 & 945 \\
\hline Primary School & 33.69 & 2842 & 34.38 & 956 \\
\hline Junior High School & 20.23 & 1706 & 18.05 & 502 \\
\hline Senior High School & 13.40 & 1130 & 10.46 & 291 \\
\hline College and above & 7.71 & 650 & 3.13 & 87 \\
\hline \multicolumn{5}{|l|}{ Mother's Education } \\
\hline Illiteracy & 53.22 & 4493 & 66.82 & 1859 \\
\hline Primary School & 24.08 & 2033 & 21.53 & 599 \\
\hline Junior High School & 11.47 & 968 & 7.15 & 199 \\
\hline Senior High School & 8.98 & 758 & 4.21 & 117 \\
\hline College and above & 2.25 & 190 & 0.29 & 8 \\
\hline \multicolumn{5}{|l|}{ Parent's political staus } \\
\hline Father’s Party Membership & 24.40 & 2880 & 22.14 & 717 \\
\hline $\begin{array}{l}\text { Mother’s Party } \\
\text { Membership }\end{array}$ & 6.79 & 802 & 3.95 & 128 \\
\hline Year of schooling (Mean) & 11.07 & 11735 & 11.03 & 3237 \\
\hline Age (Mean) & 39.06 & 11803 & 41.03 & 3238 \\
\hline
\end{tabular}




\begin{tabular}{lcccc}
\hline Earnings (mean) & 12263 & 7442 & 12167 & 2318 \\
Years Since Migration & & & 20.85 & 3238 \\
Number of Observations & & 11803 & & 3238 \\
\hline
\end{tabular}

Table 9 Determinants of Being Employed. (Urban residents aged 16-60)

\begin{tabular}{|c|c|c|c|}
\hline & $\begin{array}{c}\text { Males and Females } \\
\text { combined }\end{array}$ & Male & Female \\
\hline \multicolumn{4}{|l|}{ Gender } \\
\hline Male & $\begin{array}{c}1.198 * * * \\
(0.048)\end{array}$ & & \\
\hline Schooling & $\begin{array}{c}0.205^{* * *} \\
(0.009)\end{array}$ & $\begin{array}{c}0.146^{* * *} \\
(0.014)\end{array}$ & $\begin{array}{c}0.235^{* * *} \\
(0.013)\end{array}$ \\
\hline \multicolumn{4}{|l|}{ Marital status } \\
\hline Married & $\begin{array}{c}0.329 * * * \\
(0.093)\end{array}$ & $\begin{array}{c}0.632 * * * \\
(0.157)\end{array}$ & $\begin{array}{c}-0.338 * * * \\
(0.126)\end{array}$ \\
\hline \multicolumn{4}{|l|}{$\begin{array}{l}\text { Not party member } \\
\text { (Reference) }\end{array}$} \\
\hline СРC Member & $\begin{array}{c}0.648 * * * \\
(0.065)\end{array}$ & $\begin{array}{c}0.454^{* * *} \\
(0.094)\end{array}$ & $\begin{array}{c}0.763 * * * \\
(0.095)\end{array}$ \\
\hline \multicolumn{4}{|l|}{ Ethnicity } \\
\hline Han & $\begin{array}{l}-0.047 \\
(0.126)\end{array}$ & $\begin{array}{c}0.011 \\
(0.192)\end{array}$ & $\begin{array}{l}-0.061 \\
(0.172)\end{array}$ \\
\hline Age & $\begin{array}{c}0.788 * * * \\
(0.019)\end{array}$ & $\begin{array}{c}0.776 * * * \\
(0.027)\end{array}$ & $\begin{array}{c}0.919 * * * \\
(0.029)\end{array}$ \\
\hline Age Squared & $\begin{array}{l}-0.010^{* * *} \\
(0.0002)\end{array}$ & $\begin{array}{l}-0.010 * * * \\
(0.0003)\end{array}$ & $\begin{array}{c}-0.012 * * * \\
(0.0004)\end{array}$ \\
\hline \multicolumn{4}{|l|}{$\begin{array}{l}\text { Urban China } \\
\text { (Reference) }\end{array}$} \\
\hline Rural China & $\begin{array}{c}0.346 * * * \\
(0.062)\end{array}$ & $\begin{array}{c}0.447 * * * \\
(0.101)\end{array}$ & $\begin{array}{c}0.293 * * * \\
(0.083)\end{array}$ \\
\hline City Dummies (76) & Yes & Yes & Yes \\
\hline Constant & $\begin{array}{c}-15.604^{* * *} \\
(0.435)\end{array}$ & $\begin{array}{c}-14.515^{* * *} \\
(0.643)\end{array}$ & $\begin{array}{c}-16.882 * * * \\
0.628)\end{array}$ \\
\hline Pseudo $\mathrm{R}^{2}$ & 0.3401 & 0.3703 & 0.3365 \\
\hline Log Likelihood & -6282.62 & -2595.55 & -3423.05 \\
\hline Predicted Correctly \% & 80.78 & 85.01 & 78.71 \\
\hline $\begin{array}{l}\text { Number of } \\
\text { Observations }\end{array}$ & 14972 & 7370 & 7602 \\
\hline
\end{tabular}

Note: standard errors in parenthesis. 
Table 10. Earnings funcitons, urban residents.

\begin{tabular}{|c|c|c|c|c|c|c|}
\hline \multirow{2}{*}{ Category } & \multicolumn{3}{|c|}{ Pooled Sample } & \multirow{2}{*}{$\begin{array}{l}\text { Urban } \\
\text { Residents }\end{array}$} & \multirow{2}{*}{$\begin{array}{l}\text { Permanent } \\
\text { Migrants }\end{array}$} & \multirow{2}{*}{$\begin{array}{l}\text { Permanent } \\
\text { Migrants }\end{array}$} \\
\hline & $\begin{array}{l}\text { Male and } \\
\text { Female }\end{array}$ & Male & Female & & & \\
\hline $\begin{array}{l}\text { Gender } \\
\text { Female } \\
\text { (reference) }\end{array}$ & & & & & & \\
\hline Male & $\begin{array}{c}0.131 * * * \\
(0.012)\end{array}$ & & & $\begin{array}{c}0.129 * * * \\
(0.014)\end{array}$ & $\begin{array}{c}0.134 * * * \\
(0.026)\end{array}$ & $\begin{array}{c}0.116 * * * \\
(0.026)\end{array}$ \\
\hline Schooling & $\begin{array}{c}0.078 * * * \\
(0.002)\end{array}$ & $\begin{array}{c}0.070 * * * \\
(0.003)\end{array}$ & $\begin{array}{c}0.090 * * * \\
(0.004)\end{array}$ & $\begin{array}{c}0.079 * * * \\
(0.003)\end{array}$ & $\begin{array}{c}0.076^{* * * *} \\
(0.004)\end{array}$ & $\begin{array}{c}0.074 * * * \\
(0.004)\end{array}$ \\
\hline $\begin{array}{l}\text { Marital status } \\
\text { Not married } \\
\text { (Reference) }\end{array}$ & & & & & & \\
\hline Married & $\begin{array}{c}0.104 * * * \\
(0.025)\end{array}$ & $\begin{array}{c}0.129 * * * \\
(0.035)\end{array}$ & $\begin{array}{l}0.080 * * \\
(0.036)\end{array}$ & $\begin{array}{c}0.105^{* * *} \\
(0.028)\end{array}$ & $\begin{array}{l}0.139 * * \\
(0.055)\end{array}$ & $\begin{array}{c}0.165^{* * *} \\
(0.055)\end{array}$ \\
\hline $\begin{array}{l}\text { Political status } \\
\text { Not party member } \\
\text { (Reference) }\end{array}$ & & & & & & \\
\hline СРC Member & $\begin{array}{c}0.165 * * * \\
(0.015)\end{array}$ & $\begin{array}{c}0.181 * * * \\
(0.018)\end{array}$ & $\begin{array}{c}0.141 * * * \\
(0.025)\end{array}$ & $\begin{array}{c}0.146 * * * \\
(0.017)\end{array}$ & $\begin{array}{c}0.201 * * * \\
(0.029)\end{array}$ & $\begin{array}{c}0.194 * * * \\
(0.029)\end{array}$ \\
\hline $\begin{array}{l}\text { Ethnicity } \\
\text { Minority } \\
\text { (Reference) }\end{array}$ & & & & & & \\
\hline Han & $\begin{array}{c}0.001 \\
(0.033)\end{array}$ & $\begin{array}{l}-0.003 \\
(0.042)\end{array}$ & $\begin{array}{c}0.030 \\
(0.054)\end{array}$ & $\begin{array}{c}0.028 \\
(0.038)\end{array}$ & $\begin{array}{l}-0.102 \\
(0.070)\end{array}$ & $\begin{array}{l}-0.094 \\
(0.070)\end{array}$ \\
\hline Age & $\begin{array}{c}0.045^{* * * *} \\
(0.005)\end{array}$ & $\begin{array}{c}0.049 * * * \\
(0.007)\end{array}$ & $\begin{array}{c}0.042 * * * \\
(0.009)\end{array}$ & $\begin{array}{c}0.042 * * * \\
(0.006)\end{array}$ & $\begin{array}{c}0.048 * * * \\
(0.011)\end{array}$ & $\begin{array}{c}0.036 * * * \\
(0.012)\end{array}$ \\
\hline Age Squared & $\begin{array}{l}-0.0004 * * * \\
(0.0001)\end{array}$ & $\begin{array}{c}-0.0005^{* * *} \\
(0.0001)\end{array}$ & $\begin{array}{c}-0.0004 * * * \\
(0.0001)\end{array}$ & $\begin{array}{l}-0.0004 * * * \\
(0.0001)\end{array}$ & $\begin{array}{l}-0.0005^{* * *} \\
(0.0001)\end{array}$ & $\begin{array}{c}-0.0004^{* *} \\
(0.0001)\end{array}$ \\
\hline $\begin{array}{l}\text { Region of birth } \\
\text { Urban China } \\
\text { (Reference) }\end{array}$ & & & & & & \\
\hline Rural China & $\begin{array}{c}0.058 * * * \\
(0.015)\end{array}$ & $\begin{array}{c}0.080^{* * *} \\
(0.020)\end{array}$ & $\begin{array}{c}0.037 \\
(0.024)\end{array}$ & & & \\
\hline $\begin{array}{l}\text { Years Since } \\
\text { Receiving Hukou }\end{array}$ & & & & & & $\begin{array}{c}0.018 * * * \\
(0.005)\end{array}$ \\
\hline $\begin{array}{l}\text { Years after } \\
\text { Getting Hukou } \\
\text { Squared }\end{array}$ & & & & & & $-0.0003^{* * *}$ \\
\hline & & & & & & $(0.0001)$ \\
\hline $\begin{array}{l}\text { City Dummies } \\
\text { (76) }\end{array}$ & Yes & Yes & Yes & Yes & Yes & Yes \\
\hline Constant & $\begin{array}{c}-0.259^{* *} \\
(0.127)\end{array}$ & $\begin{array}{l}-0.136 \\
(0.169)\end{array}$ & $\begin{array}{c}-0.336^{*} \\
(0.201)\end{array}$ & $\begin{array}{l}-0.257^{*} \\
(0.143)\end{array}$ & $\begin{array}{c}0.068 \\
(0.338)\end{array}$ & $\begin{array}{c}0.135 \\
(0.341)\end{array}$ \\
\hline $\begin{array}{l}\text { Adjusted } \mathrm{R}^{2} \\
\text { Number of } \\
\text { Observations }\end{array}$ & $\begin{array}{c}0.3271 \\
9845\end{array}$ & $\begin{array}{c}0.3226 \\
5493\end{array}$ & $\begin{array}{c}0.3147 \\
4352\end{array}$ & $\begin{array}{c}0.3213 \\
7501\end{array}$ & $\begin{array}{c}0.3519 \\
2344\end{array}$ & $\begin{array}{c}0.3574 \\
2344\end{array}$ \\
\hline
\end{tabular}


Notes (1) the dependent variable is log of hourly wage. (2) standard errors in parenthesis.

Table 10. Earnings functions, urban residents. (continuation)

Estimates for permanent migrants by gender

\begin{tabular}{|c|c|c|c|c|}
\hline & Male & Female & Male & Female \\
\hline Schooling & $\begin{array}{c}0.065^{* * *} \\
(0.005)\end{array}$ & $\begin{array}{c}0.091 * * * \\
(0.007)\end{array}$ & $\begin{array}{c}0.064^{* * *} \\
(0.005)\end{array}$ & $\begin{array}{c}0.085^{* * *} \\
(0.008)\end{array}$ \\
\hline \multicolumn{5}{|l|}{$\begin{array}{l}\text { Marital status } \\
\text { Not married } \\
\text { (Reference) }\end{array}$} \\
\hline Married & $\begin{array}{c}0.214^{* * *} \\
(0.081)\end{array}$ & $\begin{array}{c}0.076 \\
(0.081)\end{array}$ & $\begin{array}{c}0.235^{* * *} \\
(0.081)\end{array}$ & $\begin{array}{c}0.103 \\
(0.081)\end{array}$ \\
\hline \multicolumn{5}{|l|}{$\begin{array}{l}\text { Political status } \\
\text { Not party member } \\
\text { (Reference) }\end{array}$} \\
\hline CPC Member & $\begin{array}{c}0.229 * * * \\
(0.034)\end{array}$ & $\begin{array}{c}0.158^{* * *} \\
(0.054)\end{array}$ & $\begin{array}{c}0.226^{* * *} \\
(0.034)\end{array}$ & $\begin{array}{c}0.148^{* * *} \\
(0.053)\end{array}$ \\
\hline \multicolumn{5}{|l|}{$\begin{array}{l}\text { Ethnicity } \\
\text { Minority } \\
\text { (Reference) }\end{array}$} \\
\hline Han & $\begin{array}{l}-0.050 \\
(0.092)\end{array}$ & $\begin{array}{l}-0.085 \\
(0.113)\end{array}$ & $\begin{array}{c}-0.049 \\
(0.092)\end{array}$ & $\begin{array}{l}-0.080 \\
(0.112)\end{array}$ \\
\hline Age & $\begin{array}{c}0.042^{* * *} \\
(0.015)\end{array}$ & $\begin{array}{c}0.069 * * * \\
(0.021)\end{array}$ & $\begin{array}{l}0.031^{* *} \\
(0.016)\end{array}$ & $\begin{array}{c}0.057 * * * \\
(0.021)\end{array}$ \\
\hline Age Squared & $\begin{array}{c}-0.0004^{* *} \\
(0.0002)\end{array}$ & $\begin{array}{c}-0.001^{* * *} \\
(0.0003)\end{array}$ & $\begin{array}{l}-0.0003 \\
(0.0002)\end{array}$ & $\begin{array}{l}-0.001^{* *} \\
(0.0003)\end{array}$ \\
\hline $\begin{array}{l}\text { Years Since } \\
\text { Receiving hukou }\end{array}$ & & & $\begin{array}{l}0.014 * * \\
(0.007)\end{array}$ & $\begin{array}{l}0.018 * * \\
(0.007)\end{array}$ \\
\hline \multirow[t]{2}{*}{$\begin{array}{l}\text { Years after } \\
\text { Getting hukou } \\
\text { Squared }\end{array}$} & & & $-0.0002 *$ & -0.0002 \\
\hline & & & $(0.0001)$ & $(0.0001)$ \\
\hline $\begin{array}{l}\text { City Dummies } \\
\text { (76) }\end{array}$ & Yes & Yes & Yes & Yes \\
\hline Constant & $\begin{array}{c}0.116 \\
(0.500)\end{array}$ & $\begin{array}{l}-0.277 \\
(0.515)\end{array}$ & $\begin{array}{c}0.209 \\
(0.504)\end{array}$ & $\begin{array}{l}-0.233 \\
(0.520)\end{array}$ \\
\hline Adjusted $\mathrm{R}^{2}$ & 0.3501 & 0.3135 & 0.3513 & 0.322 \\
\hline $\begin{array}{l}\text { Number of } \\
\text { Observations }\end{array}$ & 1381 & 963 & 1381 & 963 \\
\hline
\end{tabular}


Table 11. People who have Received Hukou through Formal/Informal Channels by Individual Characteristics. (Employed persons aged 16-60)

\begin{tabular}{|c|c|c|c|c|c|c|}
\hline \multirow{2}{*}{$\begin{array}{c}\text { Channel to receive } \\
\text { Hukou } \\
\text { Employment Sector }\end{array}$} & \multicolumn{3}{|c|}{ Formal } & \multicolumn{3}{|c|}{ Informal } \\
\hline & $\begin{array}{l}\text { White } \\
\text { collar }\end{array}$ & Blue collar & $\begin{array}{l}\text { White and } \\
\text { Blue collar }\end{array}$ & $\begin{array}{l}\text { White } \\
\text { collar }\end{array}$ & Blue collar & $\begin{array}{l}\text { White and } \\
\text { blue collar }\end{array}$ \\
\hline Male (\%) & 72.8 & 67.7 & 71.9 & 44.4 & 47.4 & 46.6 \\
\hline Han (\%) & 94.0 & 96.5 & 94.4 & 100.00 & 98.7 & 99.1 \\
\hline CPC Member (\%) & 62.1 & 32.8 & 56.9 & 25.4 & 7.1 & 12.3 \\
\hline Married (\%) & 97.1 & 96.0 & 96.9 & 88.9 & 87.8 & 88.1 \\
\hline Age (years) & 41.3 & 40.2 & 41.1 & 37.7 & 38.5 & 38.3 \\
\hline $\begin{array}{l}\text { Years of Schooling } \\
\text { (average) }\end{array}$ & 13.5 & 11.2 & 13.08 & 11.4 & 9.1 & 9.8 \\
\hline $\begin{array}{l}\text { Years Since } \\
\text { Receiving Hukou }\end{array}$ & 21.1 & 20.8 & 21.1 & 16.1 & 13.4 & 14.1 \\
\hline $\begin{array}{l}\text { Family Size (mean } \\
\text { value) }\end{array}$ & 3.1 & 3.2 & 3.2 & 3.5 & 3.40 & 3.4 \\
\hline $\begin{array}{l}\text { Hours Worked (per } \\
\text { year) }\end{array}$ & 2120 & 2288 & 2150 & 2105 & 2542 & 2417 \\
\hline Wage (per year) & 14828 & 10592 & 14065 & 14300 & 8816 & 10390 \\
\hline Hourly Wage & 7.5 & 5.0 & 7.0 & 6.9 & 3.6 & 4.6 \\
\hline Log Hourly Wage & 1.8 & 1.4 & 1.8 & 1.8 & 1.0 & 1.2 \\
\hline $\begin{array}{c}\text { Number of } \\
\text { Observations }\end{array}$ & 916 & 201 & 1117 & 63 & 156 & 219 \\
\hline Composition & $82.0 \%$ & $18.0 \%$ & $100 \%$ & $28.8 \%$ & $71.2 \%$ & $100 \%$ \\
\hline
\end{tabular}

Table 12. Decomposition of Income Differential between migrants following career routes and their counterparts with more recent routes

\begin{tabular}{lll}
\hline & Differential & \% of total \\
\hline Total & 0.5800 & 100 \\
& & \\
Intraoccupational & 0.3466 & 59.76 \\
$\quad$ Explained & 0.1442 & 24.86 \\
$\quad$ Unexplained & 0.2024 & 34.90 \\
& & \\
Interoccupational & 0.2344 & 40.24 \\
$\quad$ Explained & 0.1396 & 24.07 \\
$\quad$ Unexplained & 0.0938 & 16.17 \\
& & \\
Total Explained & 0.2838 & 48.93 \\
Total Unexplained & 0.2962 & 51.37 \\
\hline
\end{tabular}


Figure 1. Permanent Migrants as percent of Urban Residents by Age Group (Source: Table 1)

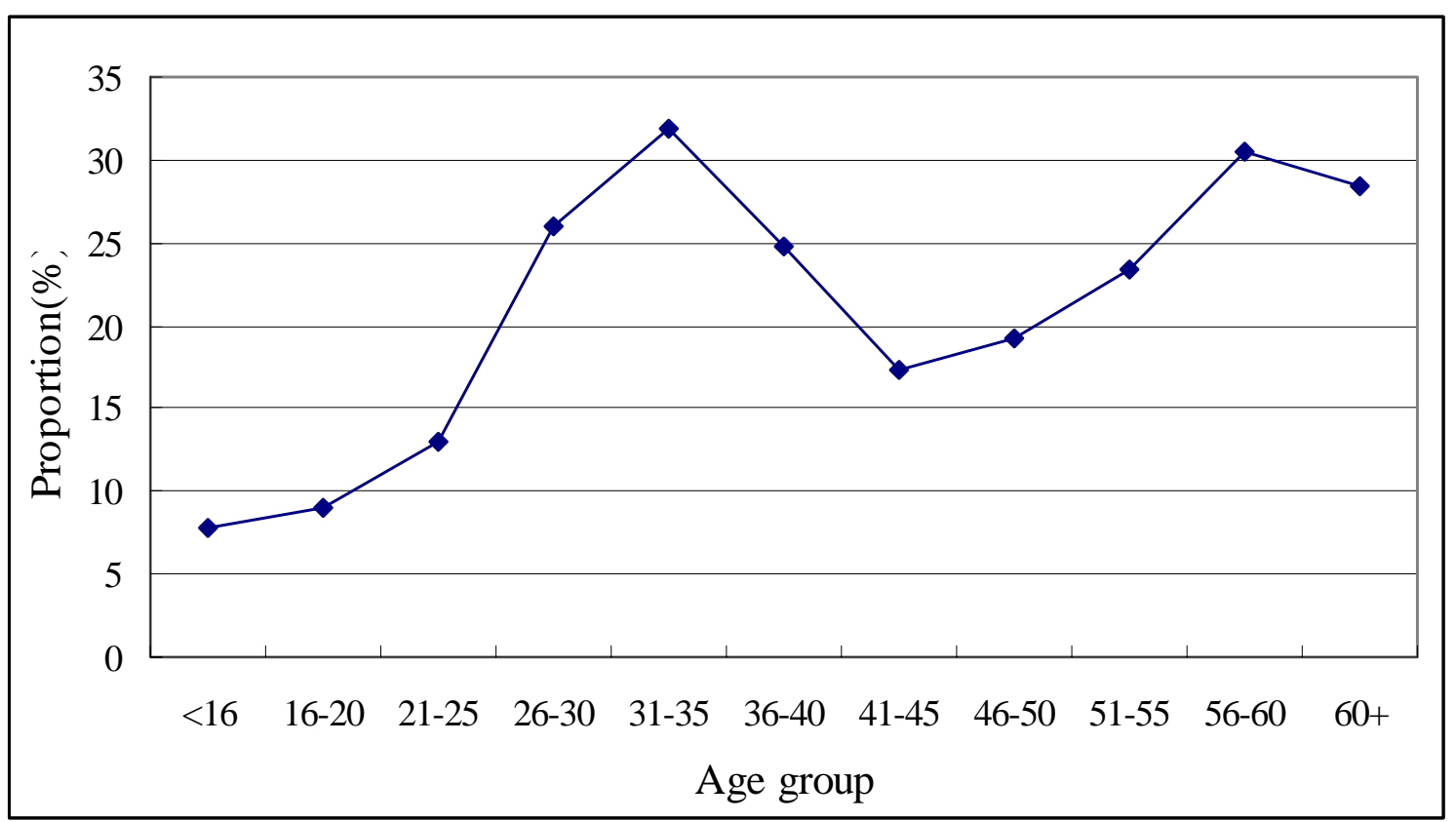


Figure 2a. Per capita income and age for various categories

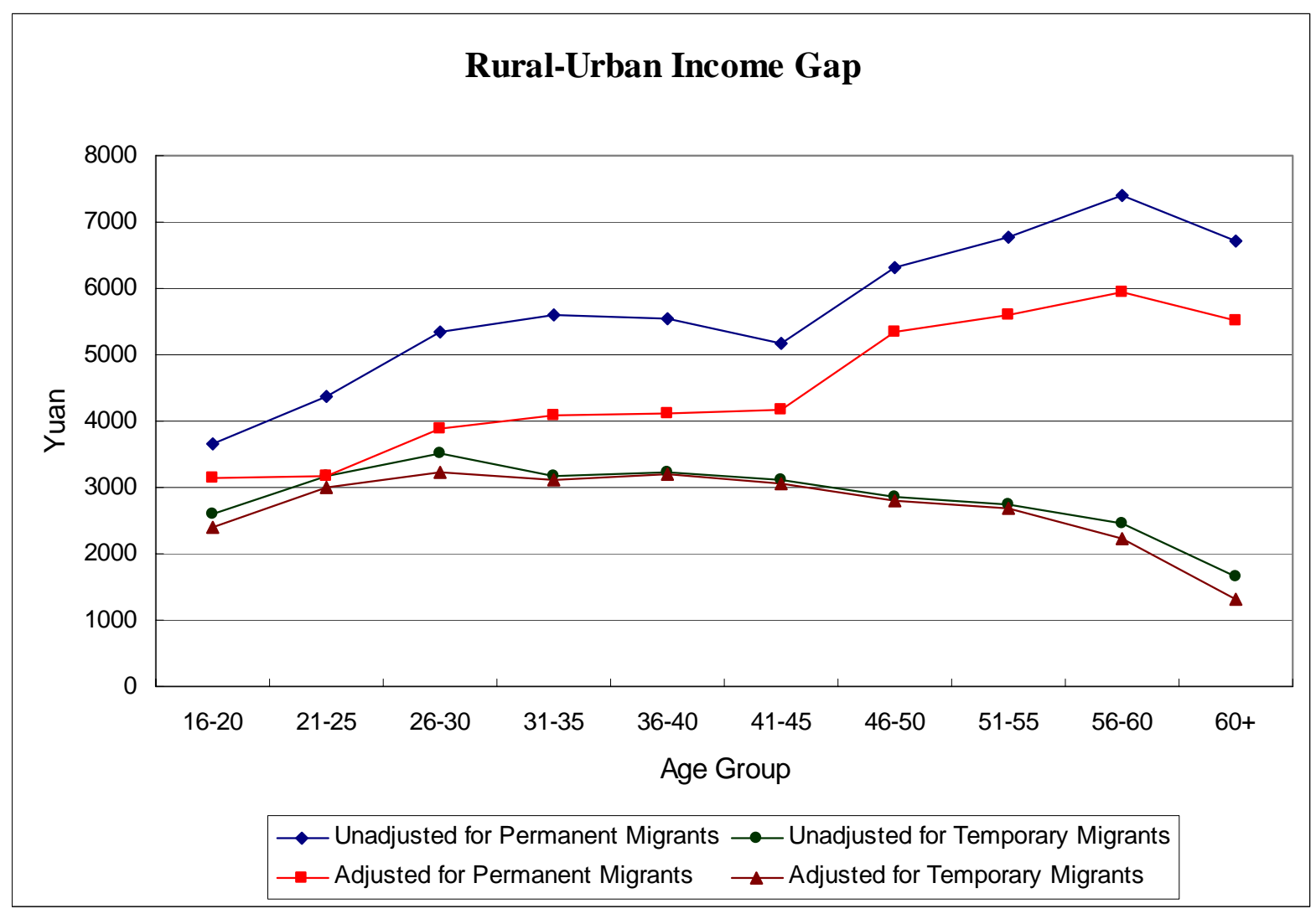

Note: Adjusted for Schooling and CPC membership 
Figure 2b. Per capita income and age for various categories (ratios)

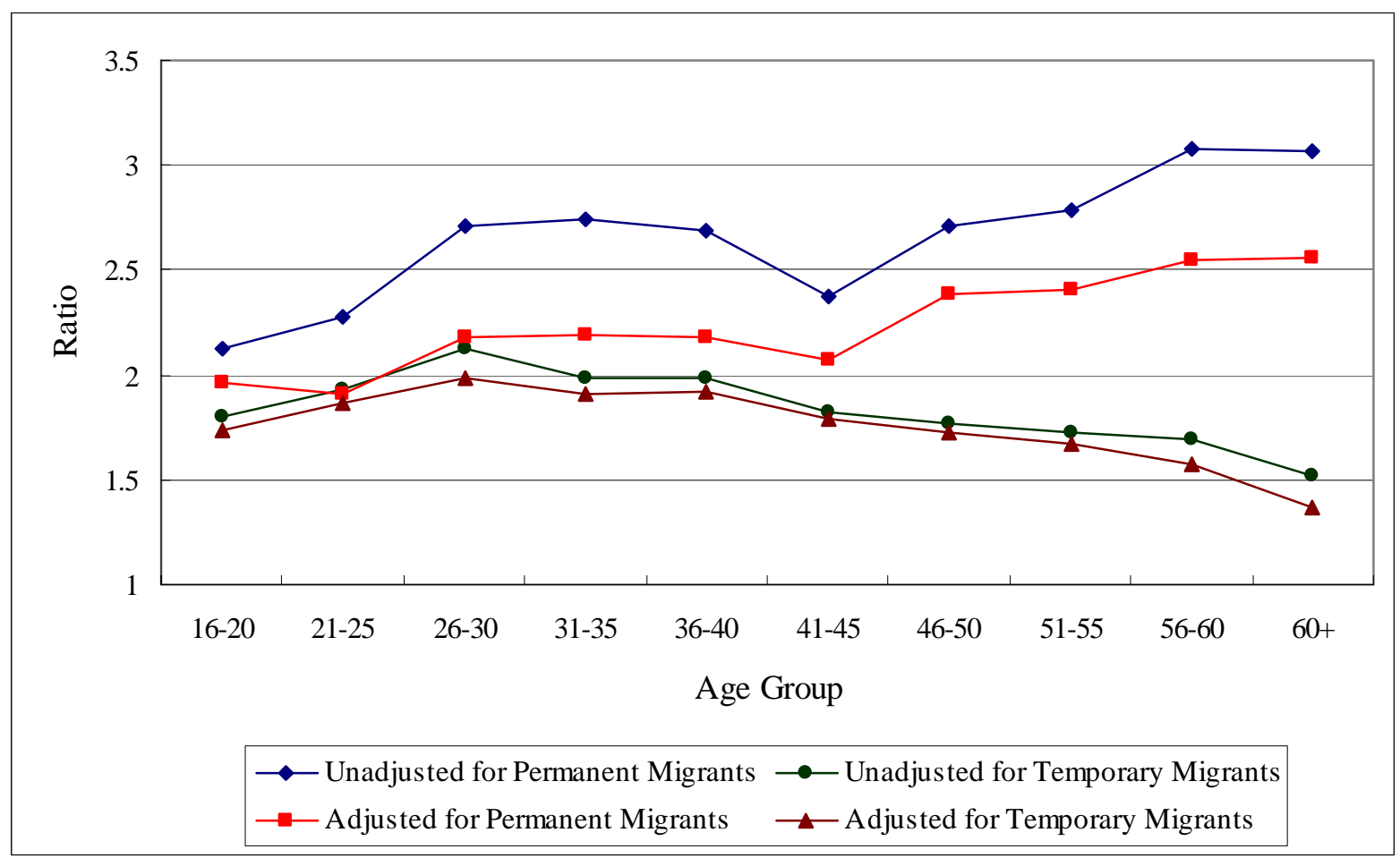

Note: Adjusted for Schooling and CPC membership 
Figure 3. Probability of being employed based on estimates presented in Table 9

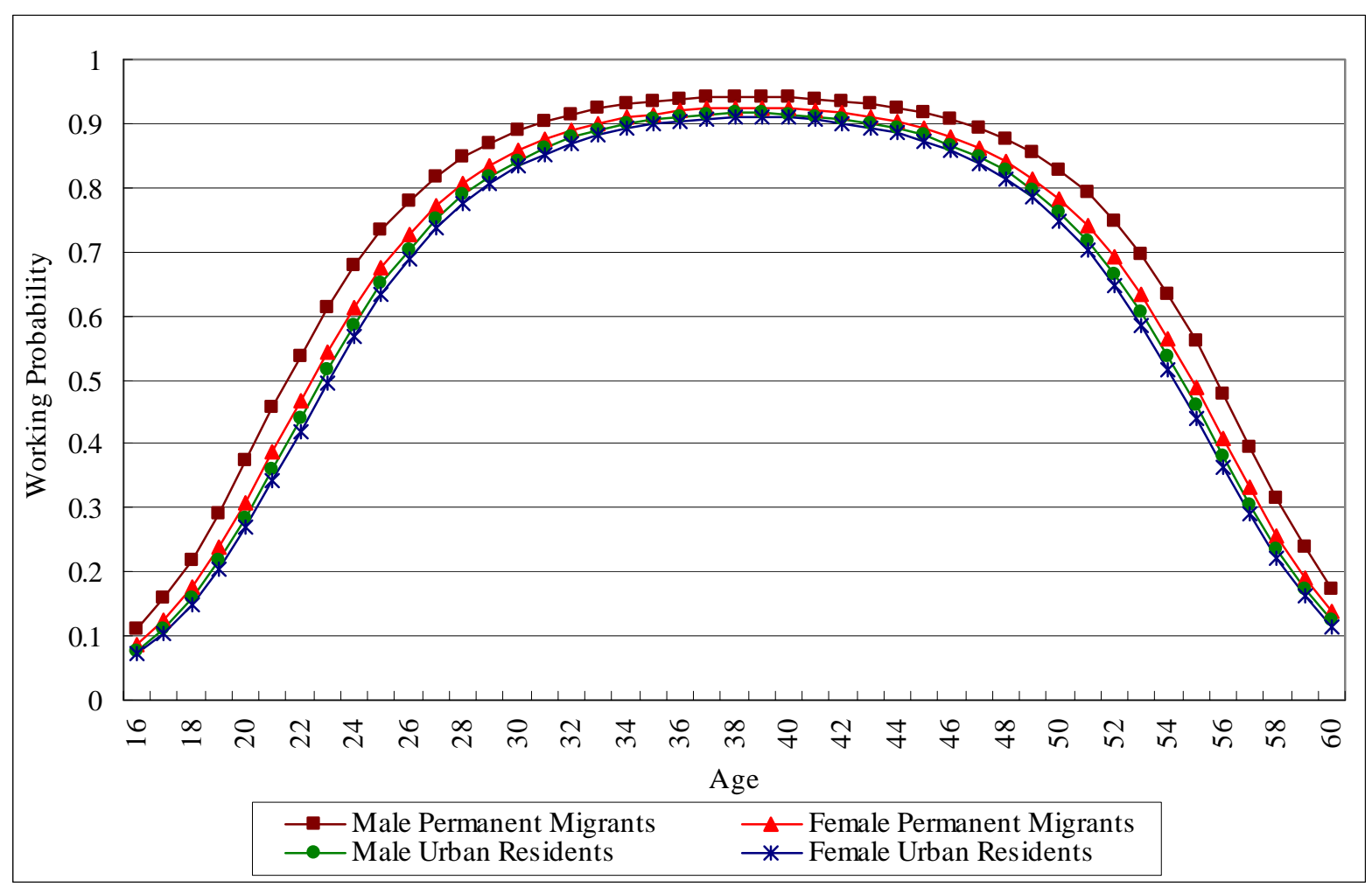

Notes: predicted at the mean level of schooling, Beijing and assuming the person has Han ethnicity, married and is not a member of CPC. 
Figure 4. Predicted Age- Income profile for urban born and permanent migrants arriving at various ages. Log Hourly Wage

Male

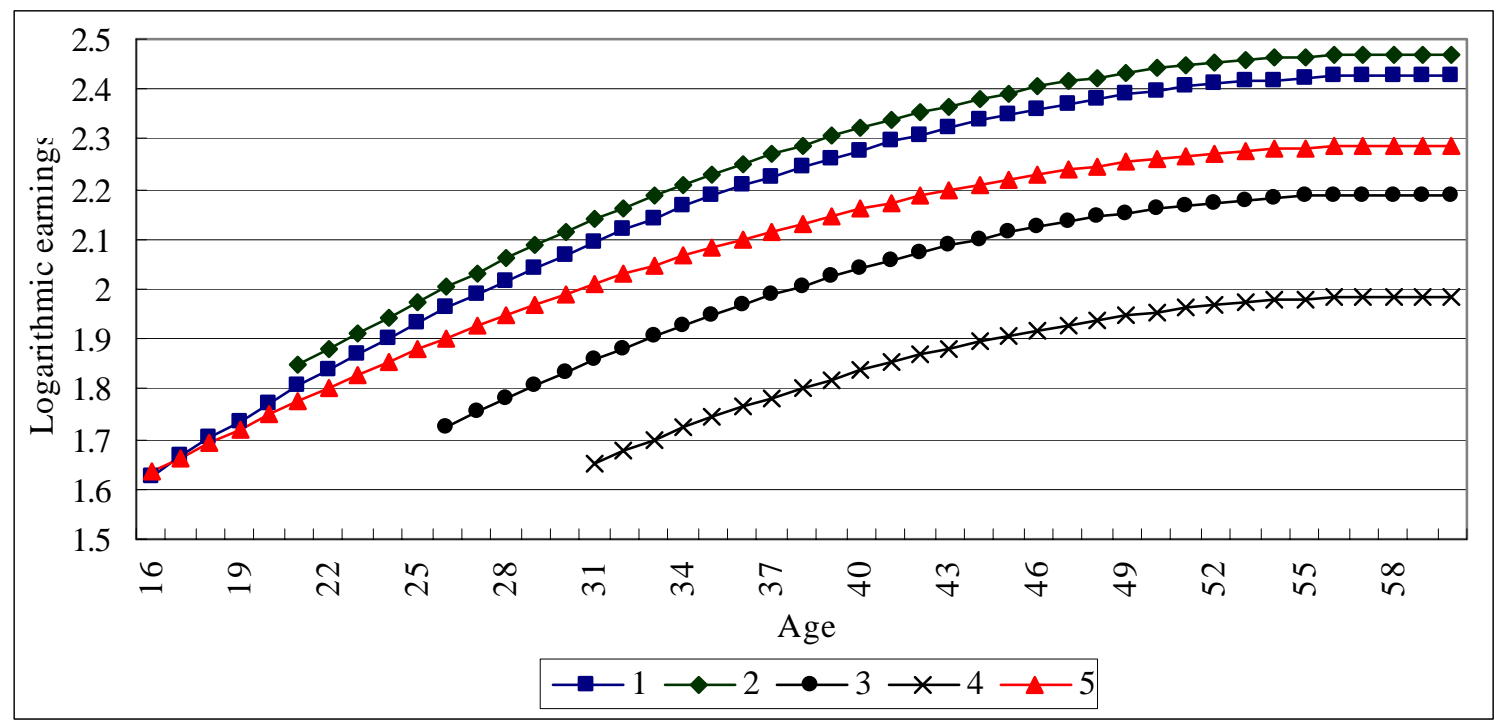

Female

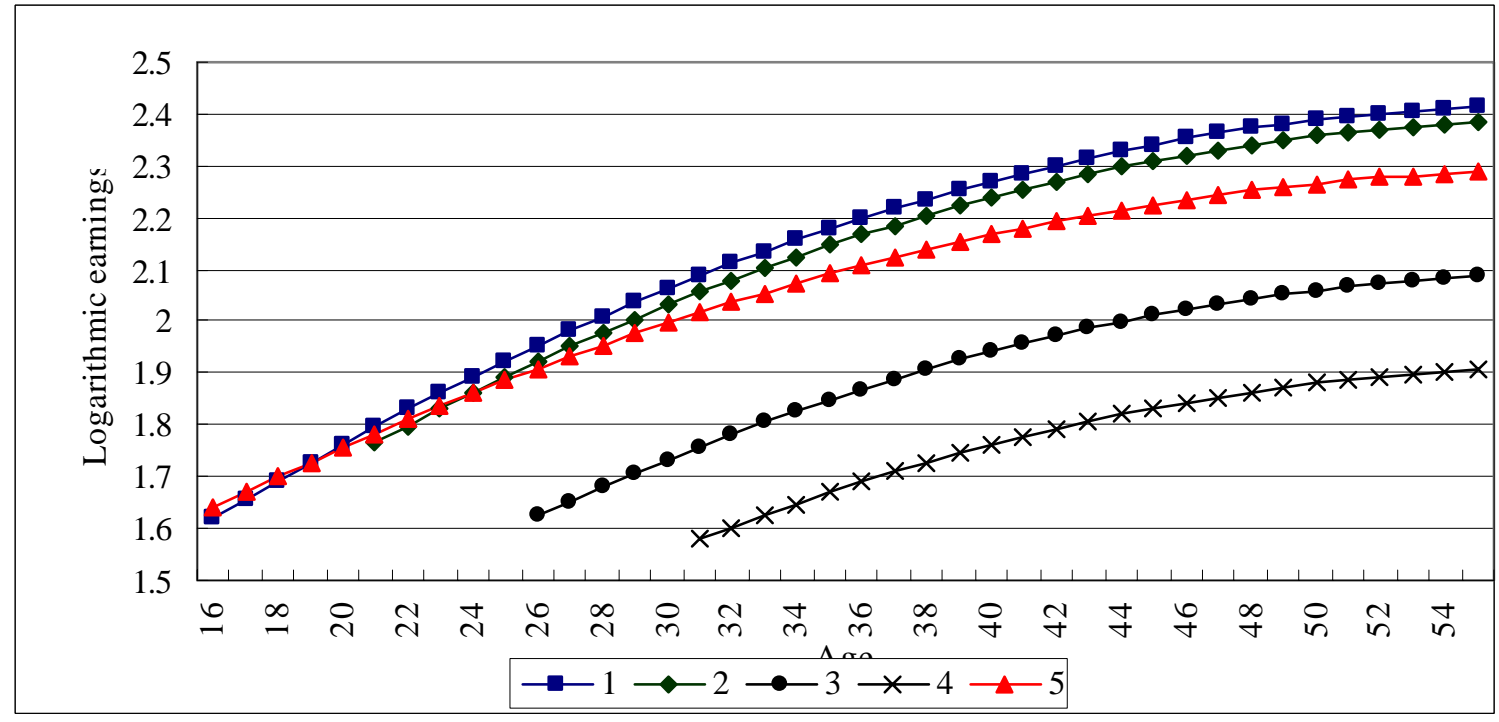

Notes: Predicted at the mean level of schooling, Beijing and assuming the person has Han ethnicity, is a member of CPC and married.

1: Migrants getting hukou before age 20

2: Migrants getting hukou between age 21 and 25

3: Migrants getting hukou between age 26 and 30

4: Migrants getting hukou after age 31

5: Urban residents 


\section{Appendix}

Table A1. Income Effects of Being a Permanent Migrant: Per capita income

\begin{tabular}{|c|c|c|c|c|c|c|}
\hline \multirow[t]{2}{*}{ Age group } & \multicolumn{3}{|c|}{$16-20$} & \multicolumn{3}{|c|}{$21-25$} \\
\hline & $\begin{array}{c}\text { Number of } \\
\text { observations }\end{array}$ & Model I & Model II & $\begin{array}{c}\text { Number of } \\
\text { observations }\end{array}$ & Model I & Model II \\
\hline Permanent Migrant & 126 & $\begin{array}{c}3663.79 * * * \\
(257.88)\end{array}$ & $\begin{array}{c}\text { 3139.86*** } \\
(253.88)\end{array}$ & 143 & $\begin{array}{c}4358.11^{* * *} \\
(271.10)\end{array}$ & $\begin{array}{c}3167.26 * * * \\
(273.27)\end{array}$ \\
\hline Temporary Migrant & 249 & $\begin{array}{c}2608.95^{* * * *} \\
(185.90)\end{array}$ & $\begin{array}{c}2406.07 * * * \\
(182.39)\end{array}$ & 391 & $\begin{array}{c}3177.75^{* * *} \\
(169.65)\end{array}$ & $\begin{array}{c}3003.57 * * * \\
(165.07)\end{array}$ \\
\hline Rural Resident & 4439 & & & 3360 & & \\
\hline Years of Schooling & & & $\begin{array}{c}308.36 * * * \\
(19.97)\end{array}$ & & & $\begin{array}{c}303.08 * * * \\
(19.39)\end{array}$ \\
\hline СРС & & & $\begin{array}{c}450.87 \\
(745.55)\end{array}$ & & & $\begin{array}{c}937.38 * * * \\
(358.75)\end{array}$ \\
\hline Constant & & $\begin{array}{c}3247.42^{* * *} \\
(42.84)\end{array}$ & $\begin{array}{c}547.14^{* * *} \\
(179.64)\end{array}$ & & $\begin{array}{c}3414.45^{* * *} \\
\quad(54.77)\end{array}$ & $\begin{array}{c}\text { 748.07*** } \\
(177.82)\end{array}$ \\
\hline Total Observations & & 4814 & 4767 & & 3894 & 3871 \\
\hline Adjusted R2 & & 0.0736 & 0.1168 & & 0.1278 & 0.1816 \\
\hline
\end{tabular}

\begin{tabular}{|c|c|c|c|c|c|c|}
\hline \multirow[t]{2}{*}{ Age group } & \multicolumn{3}{|c|}{$26-30$} & \multicolumn{3}{|c|}{$31-35$} \\
\hline & $\begin{array}{l}\text { Number of } \\
\text { observations }\end{array}$ & Model I & Model II & $\begin{array}{c}\text { Number of } \\
\text { observations }\end{array}$ & Model I & Model II \\
\hline Permanent Migrant & 265 & $\begin{array}{c}5331.31 * * * \\
(271.82)\end{array}$ & $\begin{array}{c}3885.21 * * * \\
(290.88)\end{array}$ & 531 & $\begin{array}{c}5609.64 * * * \\
(186.16)\end{array}$ & $\begin{array}{c}4085.39 * * * \\
(216.85)\end{array}$ \\
\hline Temporary Migrant & 803 & $\begin{array}{c}3506.34 * * * \\
(170.41)\end{array}$ & $\begin{array}{c}3235.10 * * * \\
(169.16)\end{array}$ & 958 & $\begin{array}{c}3167.19 * * * \\
(147.11)\end{array}$ & $\begin{array}{c}3103.01 * * * \\
(145.70)\end{array}$ \\
\hline Rural Resident & 2553 & & & 2839 & & \\
\hline Years of Schooling & & & $\begin{array}{c}340.45^{* * *} \\
(27.91)\end{array}$ & & & $\begin{array}{c}291.97 * * * \\
(24.13)\end{array}$ \\
\hline СРC & & & $\begin{array}{c}401.67 \\
(381.68)\end{array}$ & & & $\begin{array}{c}569.80 * * \\
(242.70)\end{array}$ \\
\hline Constant & & $\begin{array}{c}3115.06 * * * \\
(83.36)\end{array}$ & $\begin{array}{l}440.26^{*} \\
(232.61)\end{array}$ & & $\begin{array}{c}3210.20 * * * \\
\quad(73.89)\end{array}$ & $\begin{array}{c}1023.52 * * * \\
(190.67)\end{array}$ \\
\hline Total Observations & & 3621 & 3591 & & 4328 & 4285 \\
\hline Adjusted R2 & & 0.1622 & 0.1963 & & 0.2109 & 0.2405 \\
\hline \multirow[t]{2}{*}{ Age group } & \multicolumn{3}{|c|}{$36-40$} & \multicolumn{3}{|c|}{$41-45$} \\
\hline & $\begin{array}{l}\text { Number of } \\
\text { observations }\end{array}$ & Model I & Model II & $\begin{array}{c}\text { Number of } \\
\text { observations }\end{array}$ & Model I & Model II \\
\hline Permanent Migrant & 564 & $\begin{array}{c}5530.58 * * * \\
(205.77)\end{array}$ & $\begin{array}{c}4112.43 * * * \\
(234.21)\end{array}$ & 362 & $\begin{array}{c}5171.44 * * * \\
(217.37)\end{array}$ & $\begin{array}{c}4175.46^{* * *} \\
(230.56)\end{array}$ \\
\hline Temporary Migrant & 854 & $\begin{array}{c}3240.37 * * * \\
(173.07)\end{array}$ & $\begin{array}{c}3192.93 * * * \\
(173.18)\end{array}$ & 309 & $\begin{array}{c}3106.29 * * * \\
(233.22)\end{array}$ & $\begin{array}{c}3059.24 * * * \\
(230.83)\end{array}$ \\
\hline Rural Resident & 3510 & & & 2696 & & \\
\hline Years of Schooling & & & $\begin{array}{c}256.73 * * * \\
(25.66)\end{array}$ & & & $\begin{array}{c}211.67 * * * \\
(24.39)\end{array}$ \\
\hline
\end{tabular}




\begin{tabular}{|c|c|c|c|c|c|c|}
\hline \multirow[t]{2}{*}{$\begin{array}{l}\text { CPC } \\
\text { Constant }\end{array}$} & \multicolumn{5}{|c|}{$\begin{array}{c}878.84 * * * \\
(228.39)\end{array}$} & \multirow{2}{*}{$\begin{array}{c}1153.98 * * * \\
(210.37) \\
2145.96 * * * \\
(185.83)\end{array}$} \\
\hline & & $(76.56)$ & $(197.83)$ & & $(74.79)$ & \\
\hline Total Observations & & 4928 & 4849 & & 3367 & 3282 \\
\hline Adjusted R2 & & 0.1589 & 0.1821 & & 0.168 & 0.2013 \\
\hline \multirow[t]{2}{*}{ Age group } & \multicolumn{3}{|c|}{$46-50$} & \multicolumn{3}{|c|}{ 51-55 } \\
\hline & $\begin{array}{c}\text { Number of } \\
\text { observations }\end{array}$ & Model I & Model II & $\begin{array}{c}\text { Number of } \\
\text { observations }\end{array}$ & Model I & Model II \\
\hline Permanent Migrant & 503 & $\begin{array}{c}6316.68 * * * \\
(180.91)\end{array}$ & $\begin{array}{c}5344.30 * * * \\
(201.54)\end{array}$ & 437 & $\begin{array}{c}6773.23 * * * \\
(217.18)\end{array}$ & $\begin{array}{c}5611.94 * * * \\
(239.03)\end{array}$ \\
\hline Temporary Migrant & 233 & $\begin{array}{c}2859.80 * * * \\
(256.45)\end{array}$ & $\begin{array}{c}2793.29 * * * \\
(257.23)\end{array}$ & 139 & $\begin{array}{c}2731.85 * * * \\
(366.74)\end{array}$ & $\begin{array}{c}2680.58 * * * \\
(366.37)\end{array}$ \\
\hline Rural Resident & 3402 & & & 2768 & & \\
\hline Years of Schooling & & & $\begin{array}{c}130.46 * * * \\
(21.27)\end{array}$ & & & $\begin{array}{c}228.01 * * * \\
(26.53)\end{array}$ \\
\hline СРС & & & $\begin{array}{c}1378.07 * * * \\
(185.00)\end{array}$ & & & $\begin{array}{c}902.79 * * * \\
(212.49)\end{array}$ \\
\hline Constant & & $\begin{array}{c}3702.94 * * * \\
(64.93)\end{array}$ & $\begin{array}{c}2792.43 * * * \\
(143.64)\end{array}$ & & $\begin{array}{c}3790.78^{* * *} \\
(80.19)\end{array}$ & $\begin{array}{c}2437.16^{* * *} \\
(165.71)\end{array}$ \\
\hline Total Observations & & 4138 & 3968 & & 3344 & 3189 \\
\hline Adjusted R2 & & 0.2365 & 0.2584 & & 0.2294 & 0.2559 \\
\hline \multirow[t]{2}{*}{ Age group } & \multicolumn{3}{|c|}{$56-60$} & \multicolumn{3}{|c|}{ AGE $>60$} \\
\hline & $\begin{array}{c}\text { Number of } \\
\text { observations }\end{array}$ & Model I & Model II & $\begin{array}{c}\text { Number of } \\
\text { observations }\end{array}$ & Model I & Model II \\
\hline Permanent Migrant & 307 & $\begin{array}{c}7399.72 * * * \\
(244.59)\end{array}$ & $\begin{array}{c}5954.24 * * * \\
(278.01)\end{array}$ & 604 & $\begin{array}{c}\text { 6701.58*** } \\
(160.81)\end{array}$ & $\begin{array}{c}5528.50 * * * \\
(188.10)\end{array}$ \\
\hline Temporary Migrant & 72 & $\begin{array}{c}2450.79 * * * \\
(475.57)\end{array}$ & $\begin{array}{c}2220.36 * * * \\
(473.04)\end{array}$ & 76 & $\begin{array}{c}1665.97 * * * \\
(443.39)\end{array}$ & $\begin{array}{c}1324.31 * * * \\
(460.80)\end{array}$ \\
\hline Rural Resident & 1766 & & & 2767 & & \\
\hline Years of Schooling & & & $\begin{array}{c}258.22 * * * \\
(30.45)\end{array}$ & & & $\begin{array}{c}217.86 * * * \\
(20.10)\end{array}$ \\
\hline СРС & & & $\begin{array}{c}873.38 * * * \\
(238.09)\end{array}$ & & & $\begin{array}{c}831.75 * * * \\
(188.44)\end{array}$ \\
\hline Constant & & $\begin{array}{c}3565.41 * * * \\
(94.13)\end{array}$ & $\begin{array}{c}2045.45^{* * *} \\
(193.36)\end{array}$ & & $\begin{array}{c}3308.05^{* * *} \\
\quad(67.52)\end{array}$ & $\begin{array}{c}2423.25^{* * *} \\
(105.59)\end{array}$ \\
\hline Total Observations & & 2145 & 2028 & & 3493 & 2811 \\
\hline Adjusted R2 & & 0.3006 & 0.3332 & & 0.332 & 0.3867 \\
\hline
\end{tabular}


Table A2. Determinants of pensions among persons aged 60 and older

\begin{tabular}{|c|c|c|c|c|}
\hline \multirow[b]{2}{*}{ Permanent Migrant } & \multicolumn{4}{|c|}{ Pensions (Yuan) } \\
\hline & $\begin{array}{l}580.92 * * \\
(273.20)\end{array}$ & $\begin{array}{c}270.60 \\
(229.07)\end{array}$ & $\begin{array}{l}592.34 * * \\
(273.47)\end{array}$ & $\begin{array}{c}282.05 \\
(229.05)\end{array}$ \\
\hline Male & $\begin{array}{l}2912.78 * * * \\
(232.76)\end{array}$ & $\begin{array}{l}2545.01 * * * \\
(195.37)\end{array}$ & $\begin{array}{c}2889.36 * * * \\
(233.23)\end{array}$ & $\begin{array}{l}2516.31 * * * \\
(195.57)\end{array}$ \\
\hline $\begin{array}{l}\text { Retired from Government and } \\
\text { Institutions }\end{array}$ & & $\begin{array}{c}6216.17 * * * \\
(222.96)\end{array}$ & & $\begin{array}{c}6228.64 * * * \\
(222.76)\end{array}$ \\
\hline Retired from enterprises & & & & \\
\hline Age & $\begin{array}{l}1238.30 * * * \\
(369.77)\end{array}$ & $\begin{array}{l}875.52 * * * \\
(309.94)\end{array}$ & & \\
\hline Age squared & $\begin{array}{l}-8.67 * * * \\
(2.64)\end{array}$ & $\begin{array}{l}-6.17 * * * \\
(2.21)\end{array}$ & & \\
\hline Aged 60-64 & & & & \\
\hline Aged 65-69 & & & $\begin{array}{c}132.72 \\
(279.50)\end{array}$ & $\begin{array}{c}46.21 \\
(233.85)\end{array}$ \\
\hline Aged 70-74 & & & $\begin{array}{c}960.67 * * * \\
(320.89)\end{array}$ & $\begin{array}{l}780.02 * * * \\
(268.53)\end{array}$ \\
\hline Aged 75-79 & & & $\begin{array}{c}455.65 \\
(428.41)\end{array}$ & $\begin{array}{c}166.61 \\
(358.55)\end{array}$ \\
\hline Aged 80+ & & & $\begin{array}{l}-568.54 \\
(631.94)\end{array}$ & $\begin{array}{l}-520.08 \\
(528.68)\end{array}$ \\
\hline City dummies & & & & \\
\hline Constant & $\begin{array}{c}-31690.23 * * \\
(12904.03)\end{array}$ & $\begin{array}{l}-20080.14 * \\
(10814.65)\end{array}$ & $\begin{array}{l}11941.86^{* * *} \\
(853.14)\end{array}$ & $\begin{array}{l}10611.93 * * * \\
(715.31)\end{array}$ \\
\hline $\begin{array}{l}\text { Adjusted R-squared } \\
\text { observations }\end{array}$ & $\begin{array}{c}0.1709 \\
1904\end{array}$ & $\begin{array}{c}0.4185 \\
1904\end{array}$ & $\begin{array}{c}0.1697 \\
1904\end{array}$ & $\begin{array}{c}0.4189 \\
1904\end{array}$ \\
\hline
\end{tabular}




\begin{tabular}{|c|c|c|c|c|}
\hline & \multicolumn{4}{|c|}{ Pension income } \\
\hline & Male & Female & Male & Female \\
\hline Permanent Migrant & $\begin{array}{c}1116.37 * * * \\
(382.93)\end{array}$ & $\begin{array}{l}-320.59 \\
(379.11)\end{array}$ & $\begin{array}{l}763.19 * * \\
(326.62)\end{array}$ & $\begin{array}{l}-543.99 * \\
(302.70)\end{array}$ \\
\hline $\begin{array}{l}\text { Retired from Government or } \\
\text { Institutions }\end{array}$ & & & $\begin{array}{c}6294.84 * * * \\
(321.76)\end{array}$ & $\begin{array}{c}6035.71^{* * * *} \\
(293.96)\end{array}$ \\
\hline Retired from enterprises & & & & \\
\hline Aged 60-64 & & & & \\
\hline Aged 65-69 & $\begin{array}{c}657.49 \\
(417.92)\end{array}$ & $\begin{array}{l}-416.18 \\
(360.46)\end{array}$ & $\begin{array}{c}452.08 \\
(356.08)\end{array}$ & $\begin{array}{l}-353.11 \\
(287.64)\end{array}$ \\
\hline Aged 70-74 & $\begin{array}{c}1899.73 * * * \\
(448.98)\end{array}$ & $\begin{array}{l}-546.25 \\
(457.23)\end{array}$ & $\begin{array}{c}1441.81^{* * *} \\
(383.09)\end{array}$ & $\begin{array}{l}-299.07 \\
(365.03)\end{array}$ \\
\hline Aged 75-79 & $\begin{array}{c}954.00 \\
(614.65)\end{array}$ & $\begin{array}{l}-145.15 \\
(584.29)\end{array}$ & $\begin{array}{c}547.88 \\
(523.88)\end{array}$ & $\begin{array}{l}-223.66 \\
(466.23)\end{array}$ \\
\hline Aged 80+ & $\begin{array}{l}1413.15 \\
(915.60)\end{array}$ & $\begin{array}{c}-3030.04^{* * *} \\
(849.78)\end{array}$ & $\begin{array}{l}1142.48 \\
(779.90)\end{array}$ & $\begin{array}{c}-2499.77^{* * *} \\
(678.55)\end{array}$ \\
\hline City dummies & Yes & Yes & Yes & Yes \\
\hline Constant & $\begin{array}{c}14527.32 * * * \\
(1241.03)\end{array}$ & $\begin{array}{l}12139.81^{* * *} \\
(1076.59)\end{array}$ & $\begin{array}{l}13090.65^{* * *} \\
(1059.48)\end{array}$ & $\begin{array}{l}10545.88^{* * *} \\
(862.53)\end{array}$ \\
\hline $\begin{array}{l}\text { Adjusted R-squared } \\
\text { observations }\end{array}$ & $\begin{array}{r}0.1223 \\
1089\end{array}$ & $\begin{array}{r}0.1184 \\
815\end{array}$ & $\begin{array}{r}0.3634 \\
1089\end{array}$ & $\begin{array}{r}0.4387 \\
815\end{array}$ \\
\hline
\end{tabular}


Table A 3. Determinants of Employment and Earnings by Channel of Receiving Hukou and by type of Occupation

\begin{tabular}{|c|c|c|c|c|c|c|}
\hline \multirow[b]{2}{*}{$\begin{array}{l}\text { Route to receive } \\
\text { Hukou }\end{array}$} & \multicolumn{3}{|c|}{$\begin{array}{l}\text { Logit Model for belonging to employment } \\
\text { sector A }\end{array}$} & \multicolumn{3}{|c|}{ Earnings Function } \\
\hline & Formal & Informal & $\begin{array}{c}\text { Formal and } \\
\text { informal } \\
\text { combined }\end{array}$ & Formal & Informal & $\begin{array}{c}\text { Formal and } \\
\text { informal } \\
\text { combined }\end{array}$ \\
\hline Age & $\begin{array}{c}0.193 * * \\
(0.083)\end{array}$ & $\begin{array}{l}-0.192 \\
(0.181)\end{array}$ & $\begin{array}{l}0.125^{*} \\
(0.076)\end{array}$ & $\begin{array}{c}0.077^{* * *} \\
(0.018)\end{array}$ & $\begin{array}{c}0.055 \\
(0.054)\end{array}$ & $\begin{array}{c}0.066^{* * *} \\
(0.017)\end{array}$ \\
\hline $\mathrm{Age}^{2}$ & $\begin{array}{l}-0.002^{*} \\
(0.001)\end{array}$ & $\begin{array}{l}0.003 \\
(0.002)\end{array}$ & $\begin{array}{l}-0.001 \\
(0.001)\end{array}$ & $\begin{array}{c}-0.001^{* * *} \\
(0.0002)\end{array}$ & $\begin{array}{l}-0.001 \\
(0.001)\end{array}$ & $\begin{array}{c}-0.001 * * * \\
(0.0002)\end{array}$ \\
\hline Schooling & $\begin{array}{l}0.405 * * * \\
(0.039)\end{array}$ & $\begin{array}{c}0.333 * * * \\
(0.073)\end{array}$ & $\begin{array}{c}0.391 * * * \\
(0.034)\end{array}$ & $\begin{array}{c}0.045^{* * * *} \\
(0.007)\end{array}$ & $\begin{array}{c}0.100 * * * \\
(0.019)\end{array}$ & $\begin{array}{c}0.055^{* * *} \\
(0.007)\end{array}$ \\
\hline $\begin{array}{c}\text { Gender } \\
\text { Female } \\
\text { (Reference) }\end{array}$ & & & & & & \\
\hline Male & $\begin{array}{l}-0.057 \\
(0.199)\end{array}$ & $\begin{array}{l}-0.182 \\
(0.338)\end{array}$ & $\begin{array}{l}-0.094 \\
(0.171)\end{array}$ & $\begin{array}{c}0.057 \\
(0.041)\end{array}$ & $\begin{array}{c}0.141 \\
(0.101)\end{array}$ & $\begin{array}{l}0.076^{* *} \\
(0.038)\end{array}$ \\
\hline $\begin{array}{l}\text { Marital status } \\
\text { Unmarried } \\
\text { (Reference) }\end{array}$ & & & & & & \\
\hline Married & $\begin{array}{l}-0.507 \\
(0.499)\end{array}$ & $\begin{array}{c}0.606 \\
(0.644)\end{array}$ & $\begin{array}{c}-0.23 \\
(0.372)\end{array}$ & $\begin{array}{l}-0.039 \\
(0.105)\end{array}$ & $\begin{array}{l}-0.100 \\
(0.187)\end{array}$ & $\begin{array}{l}-0.091 \\
(0.088)\end{array}$ \\
\hline $\begin{array}{l}\text { Political status } \\
\text { Not member of } \\
\text { CPC (Reference) }\end{array}$ & & & & & & \\
\hline Member of CPC & $\begin{array}{l}1.170 * * * \\
(0.199)\end{array}$ & $\begin{array}{c}1.227^{* *} \\
(0.486)\end{array}$ & $\begin{array}{c}1.178^{* * *} \\
(0.182)\end{array}$ & $\begin{array}{c}0.151^{* * *} \\
(0.038)\end{array}$ & $\begin{array}{c}0.212 \\
(0.161)\end{array}$ & $\begin{array}{c}0.165^{* * *} \\
(0.038)\end{array}$ \\
\hline $\begin{array}{c}\text { Rout to receive } \\
\text { Hukou } \\
\text { Informal } \\
\text { (Reference) }\end{array}$ & & & & & & \\
\hline Formal & & & $\begin{array}{c}1.172^{* * * *} \\
(0.205)\end{array}$ & & & $\begin{array}{c}0.237 * * * \\
(0.053)\end{array}$ \\
\hline Constant & $\begin{array}{c}-8.175^{* * *} \\
(1.643)\end{array}$ & $\begin{array}{c}-1.453 \\
(3.382)\end{array}$ & $\begin{array}{c}-7.959^{* * *} \\
(1.484)\end{array}$ & $\begin{array}{c}-0.734 * * \\
(0.367)\end{array}$ & $\begin{array}{c}-0.982 \\
(1.031)\end{array}$ & $\begin{array}{c}-0.823^{* *} \\
(0.344)\end{array}$ \\
\hline Pseudo $\mathrm{R}^{2}$ & 0.1945 & 0.1557 & 0.3067 & & & \\
\hline Adjusted $\mathrm{R}^{2}$ & & & & 0.1070 & 0.1317 & 0.1858 \\
\hline Sample Size & 1117 & 219 & 1336 & 1104 & 212 & 1316 \\
\hline
\end{tabular}


Earnings Function (cont.)

\begin{tabular}{|c|c|c|c|c|}
\hline \multirow{2}{*}{$\begin{array}{c}\text { Rout to receive } \\
\text { Hukou } \\
\text { Employment } \\
\text { Sector }\end{array}$} & \multicolumn{2}{|c|}{ Formal } & \multicolumn{2}{|c|}{ Informal } \\
\hline & A & B & A & B \\
\hline Age & $\begin{array}{c}0.080^{* * *} \\
(0.019)\end{array}$ & $\begin{array}{c}0.021 \\
(0.487)\end{array}$ & $\begin{array}{l}-0.006 \\
(0.084)\end{array}$ & $\begin{array}{c}0.112^{*} \\
(0.064)\end{array}$ \\
\hline $\mathrm{Age}^{2}$ & $\begin{array}{c}-0.001 * * * \\
(0.0002)\end{array}$ & $\begin{array}{l}-0.0002 \\
(0.0006)\end{array}$ & $\begin{array}{l}0.0002 \\
(0.001)\end{array}$ & $\begin{array}{c}-0.001 \\
(0.0008)\end{array}$ \\
\hline Schooling & $\begin{array}{c}0.034^{* * *} \\
(0.008)\end{array}$ & $\begin{array}{c}0.020 \\
(0.018)\end{array}$ & $\begin{array}{c}0.038 \\
(0.034)\end{array}$ & $\begin{array}{c}0.085^{* * *} \\
(0.024)\end{array}$ \\
\hline $\begin{array}{c}\text { Gender } \\
\text { Female } \\
\text { (Reference) }\end{array}$ & & & & \\
\hline Male & $\begin{array}{c}0.017 \\
(0.423)\end{array}$ & $\begin{array}{c}0.314^{* * *} \\
(0.109)\end{array}$ & $\begin{array}{l}-0.053 \\
(0.167)\end{array}$ & $\begin{array}{c}0.249 * * \\
(0.116)\end{array}$ \\
\hline $\begin{array}{l}\text { Marital Status } \\
\text { Not married } \\
\text { (Reference) }\end{array}$ & & & & \\
\hline Married & $\begin{array}{l}-0.056 \\
(0.108)\end{array}$ & $\begin{array}{c}0.377 \\
(0.306)\end{array}$ & $\begin{array}{l}-0.172 \\
(0.285)\end{array}$ & $\begin{array}{l}-0.138 \\
(0.225)\end{array}$ \\
\hline $\begin{array}{l}\text { Political status } \\
\text { Not party member } \\
\text { (Reference) }\end{array}$ & & & & \\
\hline CPC & $\begin{array}{c}0.137 * * * \\
(0.040)\end{array}$ & $\begin{array}{l}-0.039 \\
(0.105)\end{array}$ & $\begin{array}{l}-0.063 \\
(0.218)\end{array}$ & $\begin{array}{c}0.139 \\
(0.233)\end{array}$ \\
\hline Constant & $\begin{array}{l}-0.572 \\
(0.408)\end{array}$ & $\begin{array}{c}0.167 \\
(0.884)\end{array}$ & $\begin{array}{c}1.461 \\
(1.713)\end{array}$ & $\begin{array}{c}-2.077^{*} \\
(1.193)\end{array}$ \\
\hline Adjusted $\mathrm{R}^{2}$ & 0.0848 & 0.0344 & -0.0774 & 0.1012 \\
\hline Sample Size & 907 & 197 & 61 & 151 \\
\hline
\end{tabular}




\section{Endnote:}

${ }^{1}$ If not stated, hukou in this paper refers to urban hukou.

2 This section builds on Zhang (1983), Cheng and Selden (1994), Chan and Zhang (1999), Lu (2002), Alexander and Chan (2004), Chan (2004), Wang (2004) and Wu and Treiman (2004).

3 The ordinary soldiers typically return to their villages and become peasants again, though they always have some advantages in productive activities or in other spheres of life compared to their fellows who have no experience from PLA.

${ }^{4}$ A temporary residence permit (zanzhuzheng) has been issued nationwide since 1985 to meet the needs of managing the increased temporary migration from the countryside. Blue Chop hukou (lanyin hukou) was implemented in the late 1980s and was approved by the Central Government in 1992. Holders of Blue Chop hukou enjoy some of the benefits of an urban hukou though the benefits vary greatly from place to place. In small cities or towns a Blue Chop hukou can be purchased. In large cities, the Blue Chop hukou is restricted to investors, house buyers and technicians or skilled workers. In 1997, the State Council selected 450 pilot counties and towns where holders of an agricultural hukou can apply for an urban hukou after two years of residency if they have stable non-agricultural jobs or income, and legal and fixed housing. However, these new hukou recipients cannot obtain the full benefits from an urban hukou in practice.

${ }^{5}$ For more information on the three surveys see Li et al. (2006). The surveys of urban residents and temporary migrants include Beijing, Shanxi, Liaoning, Jiangsu, Anhui, Henan, Hubei, Guangdong, Chongqing, Sichuan, Yunnan, and Gansu. The rural sample includes Beijing, Hebei, Shanxi, Liaoning, Jilin, Jiangsu, Zhejiang, Anhui, Jiangxi, Shandong, Henan, Hubei, Hunan, Guangdong, Guangxi, Chongqing, Sichuan, Guizhou, Yunnan, Shaanxi, Gansu and Xinjiang.

6 It could be underestimated, however, since the family members staying in cities with migrant workers are not taken into consideration.

${ }^{7}$ Information on these variables is obtained from the data.

${ }^{8}$ Urban and rural population account for $39.09 \%$ and $60.91 \%$, respectively, of the entire population of China in 2002, (NBS, 2005). Our rural sample is slightly overrepresented (64.79\%) so we expand the urban sample through random sampling while keeping the ratio of permanent migrants in the urban population unchanged.

${ }^{9}$ There are only very few rural-born individuals with both parents having long educations in our sample.

${ }^{10}$ The parameter estimates are reported in an Appendix 1 of the paper.

${ }^{11}$ Another comparison of interest to make is now people from main land China are faring in the labour market of Hong Kong. Liu et al (2004) show a substantial earnings gap between immigrants from main land China and natives, particularly for newly immigrated persons. However, occupational segregation gets smaller as the duration of residence rises and does not exist for immigrants who came to Hong Kong as young adults. 
${ }^{12}$ The remaining 1608 working persons did not answer the question, choose more than one alternative route or the alternative "other" as posed in the survey. 